\title{
Medicines used in respiratory diseases only seen in children
}

\author{
W. Lenney, A.L. Boner, L. Bont, A. Bush, K-H. Carlsen, E. Eber, B. Fauroux, M. Götz, \\ A. Greenough, J. Grigg, J. Hull, J. Kimpen, M. Sánchez Luna and F.M. de Benedictis
}

ABSTRACT: Detailed literature searches were carried out in seven respiratory disease areas. Therapeutic evidence for efficacy of medicinal products was assessed using the Grades of Recommendation, Assessment and Evaluation (GRADE) methodology, as well as an assessment of safety and side-effects.

Systemic corticosteroids may reduce the development of bronchopulmonary dysplasia but have serious side-effects. Antioxidants need further study to demonstrate whether they have long-term benefits. Treatments for acute bronchiolitis have shown little benefit but new antiviral and monoclonal antibodies need further assessment. Well-constructed studies are needed to confirm the value of inhaled corticosteroids and/or montelukast in the management of viralinduced wheeze. Corticosteroids are the treatment of choice in croup. Minimal or no information is available for the treatment of congenital lung abnormalities, bronchiolitis obliterans and interstitial lung disease.

KEYWORDS: Bronchiolitis, bronchiolitis obliterans, bronchopulmonary dysplasia, croup, interstitial lung disease, viral-induced wheeze

$\mathrm{T}$ here is a lack of evidence about the treatment of respiratory diseases that only occur in children. This report summarises work undertaken by a European Respiratory Society (ERS) task force, which successfully applied for funding to inform those caring for children with such diseases. The application was in parallel to a separate task force reviewing treatment of respiratory diseases occurring in children and adults. Seven categories of diseases were selected: bronchopulmonary dysplasia (BPD), sequelae of congenital lung abnormalities, acute viral bronchiolitis (AVB), croup, viral wheeze, bronchiolitis obliterans and paediatric interstitial lung disease (ILD), based on prevalence and priority for future research. The evidence for medicinal use in these seven diseases varies widely. European Union paediatric medicinal regulations have highlighted the lack of studies in children. The aims of this report are to summarise what evidence we have and to recommend where future research should be focused.

\section{METHODS}

Literature searches were run to identify material relating to the seven selected diseases. For each disease, a literature search was carried out based on a predefined series of keywords. Searching included the Cochrane library, MEDLINE and EMBASE, and the strategies included filters to limit the results by study type (reviews, randomised controlled trials (RCTs) and other types of experimental research) and by age range (0-18 yrs). The details of the search strategies are available on request. In most cases the results were limited to English language material. No date limits were applied.

Each subgroup, consisting of two people, reviewed the retrieved references for each disease, adding additional papers from personal files if needed. The evidence from selected papers was graded, using the method described by the Grades of Recommendation, Assessment and Evaluation (GRADE) working group in 2004, as high-, moderate-, low- or very low-grade evidence, based on the following criteria: study design and quality (systematic reviews and RCTs: high quality; observational studies: low quality; any other type of article: very low quality), consistency of the data and relevance [1]. A draft report was prepared by each subgroup which was submitted to the whole task force for comments. The reports were
AFFILIATIONS

For affiliation details, please see the Acknowledgements section.

CORRESPONDENCE

W. Lenney

Academic Dept of Child Health University Hospital of North Staffordshire and Keele University Stoke-on-Trent ST4 6QG UK E-mail: warren.lenney@uhns.nhs.uk

Received:

Nov 042008

Accepted after revision:

March 182009 
combined by the task force chairs (W. Lenney and F.M. de Benedictis) and recommendations were developed using the GRADE methodology. This enabled a more readily interpretable system of categorising recommendations in four groups: should (or should not) be done, or probably should (or should not) be done. Recommendations could only be categorised as "should (or should not) be done" when the entire task force unanimously endorsed this recommendation.

The task force found that the evidence on which to base recommendations is very limited for some diseases. When no evidence was available, narrative reviews and published expert opinions were considered for inclusion in the report.

\section{BRONCHOPULMONARY DYSPLASIA Definition}

Pre-term babies still requiring additional oxygen at gestational age 36 weeks.

\section{Prevention of BPD: the evidence base}

\section{Surfactant}

Since treatment with exogenous surfactant was first reported [2], studies have shown it reduces mortality and air leaks [312]. In one trial, synthetic surfactant was associated with a reduction in BPD development [13]. Meta-analysis of five RCTs also demonstrated synthetic surfactant in established respiratory distress syndrome (RDS) reduced the risk of BPD [3].

\section{Vitamin A}

Vitamin A is needed in the fetal lung for cellular differentiation and surfactant synthesis. Very low birth weight infants are frequently deficient in vitamin A. Several RCTs have been undertaken to determine its efficacy to prevent BPD. A Cochrane review reported vitamin A supplementation reduces death or oxygen requirement at 1 month of age and oxygen requirement at 36 weeks [14]. In six of the studies in the review, vitamin A was given by intramuscular injection [1520], in two it was given orally [21, 22]. The dose and the frequency varied [23]. High levels of vitamin A can cause neurological signs and symptoms. Neuro-developmental outcome is only available for one study [23]. The optimum vitamin A dose and route of administration require further studies.

\section{Systemic corticosteroids}

\section{Dexamethasone}

The efficacy of early administration (within $96 \mathrm{~h}$ of birth) has been examined in 21 studies showing a reduction in BPD development [24]. Seven studies examined the results of administration between 7 and 14 days showing a reduction in BPD and ability to extubate [25]. Meta-analysis of 20 RCTs studying 2,064 infants showed the relative risk for cerebral palsy was increased in those receiving early treatment [26]; therefore, use of systemic corticosteroids cannot be recommended.

Various strategies have tried to improve the risk/benefit ratio, including a lower dosage. Infants of $<28$ weeks' gestation were randomised to receive 10 days of dexamethasone $0.89 \mathrm{mg} \cdot \mathrm{kg}^{-1}$ or placebo [27]. BPD development was unchanged but dexamethasone allowed earlier extubation. No difference in death or major disability was seen at 2 yrs [28].

\section{Hydrocortisone}

A pilot study suggested early low-dose hydrocortisone might increase survival without BPD [29]. A multicentre RCT, however, was halted prematurely due to an increased rate of gastrointestinal perforation in the hydrocortisone-treated infants. Overall, there was no significant difference in BPDfree survival and mortality but hydrocortisone was associated with a lower mortality and improved survival without BPD in the subgroup exposed to chorioamnionitis [30]. In another RCT, oxygen-free survival was higher in infants who received hydrocortisone [31]. The latter study, however, was halted prematurely and no conclusion can be drawn regarding the efficacy and safety of hydrocortisone.

\section{Inhaled corticosteroids}

Meta-analysis of the results of 11 RCTs in which inhaled corticosteroids were given before 2 weeks of age showed no reduction in BPD development [32].

\section{Nitric oxide}

Inhaled nitric oxide (iNO) selectively decreases pulmonary vascular resistance and improves oxygenation. It reduces the need for extracorporeal membrane oxygenation in newborns with severe hypoxic respiratory failure and pulmonary hypertension [33].

It was proposed that iNO would decrease the need for a high oxygen requirement and ventilatory support in pre-term infants with RDS. It can prolong bleeding time [34] and inhibit platelet aggregation [35], hence the concerns regarding intracranial haemorrhage [36].

A systematic review has been performed of 11 RCTs which used iNO [37]. The studies were separated into three groups. Meta-analysis of seven RCTs demonstrated that iNO given as early rescue therapy in the first 3 days of life resulted in no significant effects on BPD development or mortality, but there was a trend towards an increased risk of severe intracranial haemorrhage. Later use of iNO resulted in no significant effect on BPD. In one trial, there was a reduction in death or BPD in infants aged 7-14 days at randomisation [38]. Routine use of iNO in intubated prematurely born infants resulted in a marginal significant reduction in the combined outcome of death or BPD and a reduction in severe intracranial haemorrhage or periventricular leukomalacia. There is no evidence from RCTs that iNO has a detrimental effect on neurodevelopmental outcome in prematurely born infants [39, 40].

Nitric oxide has anti-inflammatory effects and promotes cell and vessel growth in the immature lung [41]. It may improve surfactant function without altering surfactant recovery or protein composition [42]. Therefore, earlier iNO therapy, before lung disease is established, might prevent BPD in less sick prematurely born infants $[37,43,44]$. The results of a large pharmaceutical (INO Therapeutics, Clinton, NJ, USA)-sponsored trial of prophylactic low-dose iNO are awaited.

\section{Other possible preventative therapies Inositol}

Inositol promotes maturation of surfactant phospholipids and the synthesis of phosphatidyl inositol in type 2 pneumocytes. Meta-analysis of two RCTs demonstrated that inositol 
supplementation significantly reduced the combined outcome of death and BPD, but not BPD alone [45].

\section{Bronchodilators}

There has only been one RCT and this showed no benefit [46].

\section{Cromolyn sodium}

No reduction in BPD was demonstrated in two small RCTs [47].

\section{Macrolide antibiotics}

Erythromycin. The relative risk of BPD development in babies colonised with Ureaplasma urealyticum is 1.7 [48]. Administration of erythromycin did not reduce this [49] but duration of therapy may have been too short [50].

Azithromycin. Macrolide antibiotics have anti-inflammatory actions and inhibit neutrophil chemotaxis and superoxide generation. In an animal model of hyperoxia, treatment with azithromycin improved survival and decreased lung damage [51]. It also reduced interleukin (IL)- 6 and IL- 8 production by tracheal cells obtained from prematurely born infants [52]. Azithromycin, however, did not reduce the incidence of BPD in infants $<1,001 \mathrm{~g}$ but was associated with less postnatal steroid use [53].

\section{Antioxidants}

Superoxide dismutase. Lung injury secondary to hyperoxia can be reduced by superoxide dismutase (SOD) [54, 55]. Prophylactic supplementation with recombinant human copper-zinc SOD reduced repeated severe wheeze during infancy, but did not reduce BPD development [56].

$\mathrm{N}$-acetyl cysteine. The synthesis of glutathionine (an endogenous scavenger of free radicals) is limited by the availability of cysteine. In a multicentre RCT, no significant differences were found in the incidence or severity of BPD [57] or in lung function [58]. $N$-acetyl cysteine, however, was started at age $36 \mathrm{~h}$ [57], which may have been too late.

Allopurinol. Xanthine oxidase generates superoxide radicals following hypoxia. Allopurinol is a synthetic inhibitor of xanthine oxidase and a free radical scavenger. In an RCT of 400 extremely premature infants, allopurinol did not reduce BPD incidence [59].

Melatonin. Melatonin, a potent free radical scavenger, upregulates antioxidant enzymes and downregulates pro-oxidant enzymes [60]. Infants with RDS treated with melatonin had lower levels of pro-inflammatory cytokines and reduced ventilatory requirements [61].

Vitamin E. Vitamin E is a scavenger of free radicals which inhibits inflammation. Meta-analysis demonstrated that vitamin E supplementation did not reduce the risk of BPD; a systematic review of 26 RCTs showed high-dose intravenous vitamin E supplementation increased the risk of sepsis [62].

Cimetidine. Cimetidine, a cytochrome P450 inhibitor, prevents gas exchange failure in newborn lambs after breathing 95\% oxygen for $72 \mathrm{~h}$ [63]. In an RCT of 84 newborn infants $<1,251 \mathrm{~g}$, cimetidine had no effect on severity of respiratory insufficiency at 10 days [64].

\section{Methylxanthines}

Caffeine. Caffeine administration has been associated with a reduction in BPD development [65]. Follow-up demonstrated a reduction in cerebral palsy [66].

Pentoxiphylline. Pentoxiphylline, a methylxanthine derivative and nonselective phosphodiesterase inhibitor, has anti-inflammatory effects. It also inhibits synthesis of intercellular adhesion molecule (ICAM)-1, which correlates with the risk of developing BPD [67]. In rat pups it reduced fibrin deposition and prolonged survival in experimental hyperoxic lung injury [68]. In five infants with BPD, nebulised pentoxiphylline reduced oxygen requirements within 5 days [69]. In an RCT of 150 very low birth weight infants, pentoxiphylline was associated with a $27 \%$ reduction in BPD development [70].

\section{Oestradiol and progesterone}

Oestradiol and progesterone are important in lung growth [71, 72 ]. In infants of $<29$ weeks' gestation, they were given for $\geqslant 2$ weeks; $48 \%$ of the placebo and $44 \%$ of the hormone group developed BPD or died, but the longer the hormones were given, the lower was the risk of BPD [73]

\section{Ethyl nitrate}

Inhaled ethyl nitrate achieves $S$-nitrosation of glutathione without releasing reactive nitrogen species [74]. It had a greater effect than nitric oxide in preventing lung myeloperoxidase accumulation and expression of cytokine-induced neutrophil chemoattractant in newborn rats [75]. Human studies in BPD are under consideration.

\section{Prevention of BPD: summary and recommendations}

For a summary of recommendations for the prevention of BPD, see table 1 .

\section{Side-effects}

1) Early (within 96 h of birth) systemic corticosteroids increase the risk of cerebral palsy, so routine use in the first weeks of life cannot be recommended.

2) High levels of vitamin A can cause neurological signs due to raised intracranial pressure.

\section{Conclusions}

1) Many therapies have been studied in RCTs but no safe and effective BPD preventative therapy has been shown.

2) Systemic corticosteroids, in the first weeks after birth, reduce $\mathrm{BPD}$, but have serious side-effects.

3) Vitamin A reduces BPD but also has side-effects. Further investigation is needed to identify the safest dose regimen.

\section{Prioritised research questions}

1) Antioxidants, such as SOD, and early low-dose iNO require further studies to determine if they can prevent BPD.

2) The positive effect of caffeine on BPD incidence is exciting. Optimum timing and dosage related to long-term outcomes merit testing. 
TABLE 1 Prevention of bronchopulmonary dysplasia (BPD)

\begin{tabular}{|c|c|c|}
\hline Surfactant & $\begin{array}{l}\text { Surfactant administration within the first } 48 \mathrm{~h} \text { after birth does not reduce the } \\
\text { risk of BPD, but reduces mortality and air leak (high) }\end{array}$ & Surfactant should be used \\
\hline Vitamin A & $\begin{array}{l}\text { Vitamin A supplementation prevents BPD development in prematurely } \\
\text { born infants (high) }\end{array}$ & $\begin{array}{l}\text { The optimum and safest dose, dosage } \\
\text { regimen and route of administration } \\
\text { require further studies }\end{array}$ \\
\hline Systemic corticosteroids & Information on hydrocortisone usage is insufficient & \\
\hline Inhaled steroids & Inhaled steroids do not reduce BPD development (high) & Inhaled steroids should not be used \\
\hline Nitric oxide & $\begin{array}{l}\text { Early rescue therapy with iNO resulted in no significant effect on BPD development } \\
\text { or mortality but showed a trend towards increased risk of severe ICH } \\
\text { Later use of iNO resulted in no significant effect on BPD development } \\
\text { Routine use of iNO resulted in a marginal reduction in death or BPD and } \\
\text { reduction in the incidence of severe ICH (high) }\end{array}$ & $\begin{array}{l}\text { Results of a large international trial } \\
\text { awaited }\end{array}$ \\
\hline Bronchodilators & Bronchodilators have no effect on preventing BPD (moderate) & Bronchodilators should not be used \\
\hline Cromolyn & Cromolyn has no effect on preventing BPD (moderate) & Cromolyn should not be used \\
\hline Macrolides & Erythromycin and azithromycin have no effect on preventing BPD (moderate) & $\begin{array}{l}\text { Erythromycin or azithromycin should not } \\
\text { be used }\end{array}$ \\
\hline \multirow[t]{5}{*}{ Antioxidants } & $\begin{array}{l}\text { SOD supplementation does not reduce BPD development, but reduces } \\
\text { repeated severe wheeze in infancy (high) }\end{array}$ & Further studies are required \\
\hline & NAC does not reduce BPD development (moderate) & NAC should not be used \\
\hline & Allopurinol does not reduce BPD development (moderate) & Allopurinol should not be used \\
\hline & Melatonin reduces ventilatory requirements during the prenatal period (moderate) & Melatonin should probably not be used \\
\hline & $\begin{array}{l}\text { Vitamin E supplementation does not reduce BPD development and may increase } \\
\text { sepsis (high) }\end{array}$ & Vitamin E should not be used \\
\hline
\end{tabular}

iNO: inhaled nitric oxide; ICH: intracranial haemorrhage; SOD: superoxide dismutase; NAC: N-acetyl cysteine.

\section{Treatment of BPD: the evidence base}

\section{Surfactant}

Ventilated pre-term infants have abnormal surfactant function with deficiency of surfactant protein A and B [76]. They also have abnormalities of surfactant kinetics, which correlate with the level of ventilatory support [77].

There have been very few studies examining surfactant use in infants with BPD. A single dose was given to 10 ventilated infants of 25 weeks' gestation. Oxygenation improved for $24 \mathrm{~h}$ [78]. Six infants who had received a repeat surfactant course were retrospectively identified; five subsequently developed BPD [79].

\section{Systemic corticosteroids}

Infants with BPD have persisting lung inflammation. In the Cochrane review assessing nine RCTs (562 infants) in which corticosteroids were given, no effect on mortality was shown [80]. One study showed a reduction in oxygen dependence at
36 weeks associated with less need for home oxygen. Adverse effects included glycosuria and hypertension, and slight increase in retinopathy of prematurity. No study has been powered to detect adverse long-term neurosensory outcomes. It is prudent to reserve use of late corticosteroids for infants who cannot be weaned from mechanical ventilation.

\section{Diuretics}

The efficacy of diuretics, including aerosolised diuretics, in infants with developing or established BPD has been assessed [81-94]. RCTs have shown short-term benefits in lung mechanics and/or oxygenation, but there have been no significant effects on long-term outcomes.

\section{Bronchodilators}

Inhaled bronchodilator therapy improves lung function and blood gases in ventilated 1-month-old babies with BPD [95]. Salbutamol resulted in a dose-dependent improvement in lung 
mechanics [96]. Synergism was seen with salbutamol and ipratropium bromide [97], but not metaproterenol and atropine [98]. Any effect was short-lasting.

\section{Pulmonary vasodilators}

Pulmonary hypertension is associated with BPD and is a recognised cause of mortality [99-101]. Abnormally high vascular reactivity is present in BPD with a marked increased vasoconstrictor response to acute hypoxia [102].

Calcium channel blockers, prostacyclin, sidenafil and endothelin-1 antagonists are potent pulmonary vasodilators and are used to treat pulmonary hypertension in infants with BPD. No RCTs have been undertaken, with most studies comprising few or single patient case reports [103-108].

\section{Nitric oxide}

iNO was given for $72 \mathrm{~h}$ to ventilator-dependent BPD infants $>4$ weeks old. 11 responded, and four of the 11 were ultimately weaned off mechanical ventilation. All infants who failed to respond either died or continued to require mechanical ventilation [109].

\section{Treatment of BPD: summary and recommendations}

For a summary of recommendations for the treatment of BPD, see table 2.

\section{Side-effects}

1) Corticosteroids increase glycosuria and hypertension; no study has been powered to detect adverse long-term neurodevelopmental outcomes.

2) Chronic diuretic therapy may cause hypercalcuria, renal calcification and nephrolithiasis leading to haematuria and urinary tract infections.

\section{Conclusions}

1) Corticosteroids should only be given to infants with severe respiratory failure and only continued beyond 3 days if there is obvious clinical response.

2) Diuretics should be reserved for infants with fluid overload.
3) Bronchodilators should be given to infants who have symptomatic wheeze.

\section{Prioritised research questions}

1) The efficacy of various pulmonary vasodilators in improving long-term outcome in BPD needs investigation.

2) The impact of BPD treatments on long-term lung function should be an essential outcome of all RCTs.

\section{CONGENITAL LUNG MALFORMATIONS}

\section{The possibility of medical treatment: the evidence base}

Although uncommon individually, congenital lung cysts, congenital cystic adenomatous malformations, lung sequestrations, congenital lobar emphysema, and tracheal and airway narrowings collectively pose management difficulties in early childhood. Post-natal therapy is either surgical excision, coil embolisation of feeding vessels, or expectant treatment, with no definite evidence to guide the paediatrician. There are no known medical therapies which lead to regression of congenital malformations. Antenatal treatment with betamethasone of mothers carrying a fetus with a congenital thoracic malformation has led to regression of the malformation and better results than historical controls [110, 111]. However, an unexpected intrauterine death associated with this treatment [112] means it is unlikely to become routine. There are no other antenatal medical therapies which are likely to be testable in the near future.

\section{Prioritised research questions}

There are none relating to medications at present.

\section{ACUTE VIRAL BRONCHIOLITIS}

\section{Treatment of AVB: the evidence base}

AVB is frequently caused by the respiratory syncytial virus (RSV) [113]. Hospitalisation rates are $\sim 1 \%$, but can be $10-20 \%$ in high-risk groups [114-116]. About 10\% hospitalised infants require mechanical ventilation [117]. Mortality is very low. AVB is followed by recurrent episodes of wheeze in $30-70 \%$ of young children.

\section{TABLE 2 Treatment of bronchopulmonary dysplasia (BPD)}

\begin{tabular}{|c|c|c|}
\hline Medicine & Quality of evidence & Recommendation \\
\hline Surfactant & $\begin{array}{l}\text { Surfactant has been given to infants with evolving or established BPD } \\
\text { only in nonrandomised trials (low) }\end{array}$ & Further studies are required \\
\hline Corticosteroids & $\begin{array}{l}\text { Corticosteroids after age } 3 \text { weeks reduce oxygen dependence and late } \\
\text { rescue steroid therapy, but have short-term adverse effects (high) }\end{array}$ & $\begin{array}{l}\text { Corticosteroids should not be routinely used, but reserved for } \\
\text { infants who cannot be weaned from mechanical ventilation } \\
\text { Use lowest and shortest dose possible }\end{array}$ \\
\hline Diuretics & $\begin{array}{l}\text { Despite short-term improvements in lung mechanics, diuretics do not } \\
\text { show subsequent benefit in BPD treatment (high) }\end{array}$ & $\begin{array}{l}\text { Diuretics should not be used routinely, but reserved for } \\
\text { infants with fluid overload }\end{array}$ \\
\hline Bronchodilators & Administration in infants with BPD improves lung mechanics (moderate) & $\begin{array}{l}\text { Bronchodilators should probably be used in wheezing infants, } \\
\text { but only continued if there is clinical improvement }\end{array}$ \\
\hline Pulmonary vasodilators & $\begin{array}{l}\text { Pulmonary vasodilators decrease pulmonary artery pressure, and iNO } \\
\text { may improve oxygenation (low) }\end{array}$ & $\begin{array}{l}\text { There is insufficient evidence to recommend the routine use } \\
\text { of pulmonary vasodilators or iNO in infants with BPD }\end{array}$ \\
\hline
\end{tabular}

iNO: inhaled nitric oxide. 


\section{Bronchodilators}

A meta-analysis concluded that bronchodilators have no effect on the course of AVB [118]. A large RCT [119] and a Cochrane review [120] stated that there is insufficient evidence to support the use of epinephrine in inpatients; however, epinephrine may be helpful in the outpatient setting [120]. Individual trial of nebulised bronchodilators may be justified, but the medication should be discontinued unless a clear positive effect is seen [121-123].

\section{Inhaled corticosteroids}

No effect of inhaled corticosteroids was seen on clinical scores or length of hospitalisation [124-126]. There is no evidence that inhaled corticosteroids prevent recurrent wheeze following AVB $[127,128]$. There are no large RCTs focusing on the longterm effects of inhaled corticosteroids in children with AVB.

\section{Systemic steroids}

A meta-analysis concluded that there is no positive effect of systemic corticosteroids on the course of AVB [129]. An RCT in hospitalised infants showed modest benefit of a single dose of dexamethasone $0.6 \mathrm{mg} \cdot \mathrm{kg}^{-1}$ on several outcomes, including length of hospital stay [130]. A large RCT did not show any effect of one dose of dexamethasone in 600 infants presenting at the emergency department [131]. One study showed benefit of i.v. dexamethasone in children mechanically ventilated for life-threatening AVB [132].

\section{Leukotriene receptor antagonists}

Increased concentrations of leukotrienes have been found in the airways of infants with AVB [133]. A recent study showed that montelukast does not improve the clinical course of AVB [134]. A preliminary study showed a beneficial effect of montelukast on post-bronchiolitis wheeze [135], but this was not confirmed in a larger study [136].

\section{Polyclonal and monoclonal antibodies}

Antibody treatment might prevent bronchiolitis in high-risk populations. Polyclonal immunoglobulins against RSV are no longer available. A Cochrane review did not show benefit in four RCTs of polyclonal immunoglobulins used as AVB treatment [137].

Palivizumab is effective as RSV prophylaxis and is used in many countries in patients at high risk of developing severe RSV disease [138]. The recommended regime is five i.m. injections at monthly intervals over the RSV season. The major restriction to its use is its high cost.

\section{Antibiotics}

Bacterial infection is rare during AVB [139]. In 1966, FIELD et al. [140] reported no positive effect of broad-spectrum $\beta$-lactam antibiotics on the course of disease in 52 patients. In 2007, TAHAN et al. [141] reported that macrolides reduced length of hospitalisation. A Dutch RCT did not show that azithromycin reduces the duration of hospitalisation [142]. The antiinflammatory effect of macrolides should be studied in RCTs in outpatient and inpatient settings.

\section{Antiviral drugs}

Small studies have been performed with ribavirin [143, 144]. The outcomes are variable on length of hospital stay, duration of mechanical ventilation and effect on post-bronchiolitic wheeze. In the absence of large RCTs the effect of ribavirin remains unproven.

\section{Chest physiotherapy}

A systematic review of physiotherapy in children aged $<24$ months has been performed [145]. The studies used different vibration and percussion techniques. There was insufficient evidence to undertake a meta-analysis.

\section{Hypertonic saline}

Three small studies evaluated the effect of aerosolised hypertonic saline (3\%) in infants [146-148]. In ambulatory patients it reduced symptom score [146]. In hospitalised infants it reduced the length of hospital stay [147]. A similar reduction of hospital stay was reported in infants receiving 3\% saline solution versus those receiving normal saline in addition to routine therapy [148]. The beneficial effect, the lack of sideeffects and the limited cost of this treatment deserve consideration for a large RCT.

\section{Treatment of AVB: summary and recommendations}

Recommendations for treatment of AVB can be found in table 3 .

\section{Side-effects}

The interventions mentioned in this article have no important side-effects.

\section{Conclusions}

AVB is a frequent cause of morbidity during early childhood. Supportive care, including administration of oxygen and fluids, is the cornerstone of treatment. There is no specific treatment with clear beneficial effect on the course of disease. Differences in clinical definition of AVB exist between countries [121, 149]. Uniformity is needed to better differentiate infants with AVB from those with other illness, and to allow a comparison between studies performed in different parts of the world. Inpatient and outpatient studies should be considered separately. In inpatient studies, length of hospital stay is important. In outpatient studies, prevention of admission should be the primary outcome.

\section{Prioritised research questions}

1) What are the safety and efficacy benefits of antiviral drugs and monoclonal antibodies in the treatment of AVB?

2) Can the beneficial effect of hypertonic saline be confirmed in large RCTs?

3) What is the effect of combined antiviral and immunomodulatory treatments on short- and long-term outcomes in AVB?

\section{VIRAL-INDUCED WHEEZE}

\section{Treatment of viral-induced wheeze: the evidence base}

The term "viral-induced wheeze" is a much used entity in preschool children defined as "wheezing only in association with viral respiratory tract infection and with no interval symptoms" [150]. However, there may be difficulties in discriminating the atopic asthmatic pre-school child from this definition [151]. 


\section{TABLE 3 Treatment of acute viral bronchiolitis}

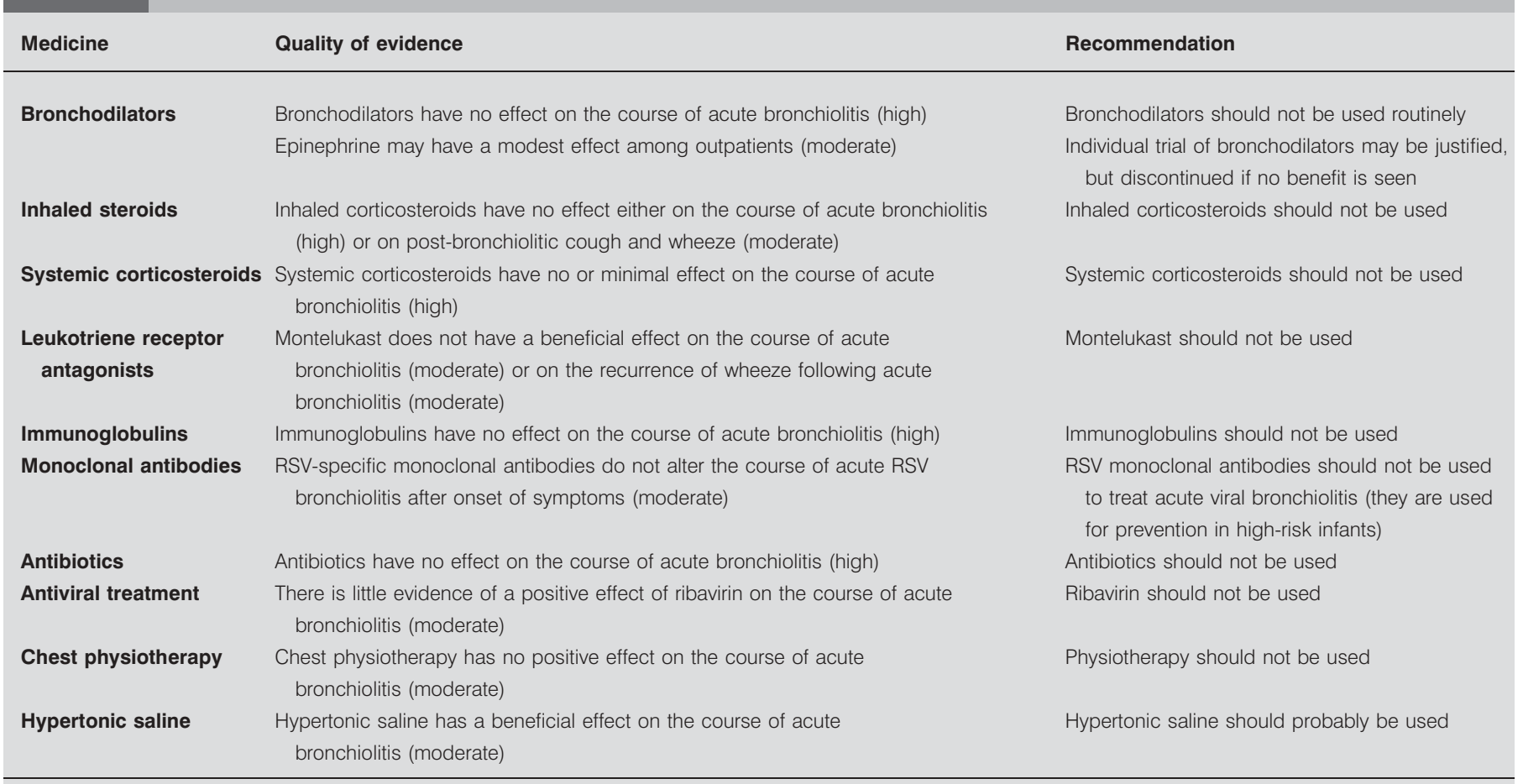

RSV: respiratory syncytial virus.

Wheeze is a word found only in the English language. It is often described as a whistling noise in the airways. In this section the terms with respect to treatment will be defined as follows. "Acute viral-wheeze": an episode or attack of wheeze in association with a clinical viral respiratory tract infection, not dependent on previous history wheeze; and "episodic viral wheeze": wheezing only in association with viral respiratory tract infection with no interval symptoms but dependent on clinical history.

SPYCHER et al. [152] published an assessment of pre-school wheeze in children from a population-based cohort. They identified five phenotypes, one being transient viral wheeze. A problem with such retrospective classification is that it is not applicable in the acute situation when the child has symptoms.

There are issues with the definition of acute viral wheeze in infants. In the USA and some European countries, infants with a major wheeze component triggered by a viral cold may be classified as having "bronchiolitis" [153]. In the UK, the diagnosis "bronchiolitis" is usually reserved for infants with the combination of acute bilateral chest crackles, wet cough, hypoxaemia and poor feeding [154]. In this review, it is assumed that some of the non-UK studies have included infants with a mix of acute viral wheeze and UK-defined "bronchiolitis".

\section{Respiratory viral infections and bronchial obstruction/ wheeze}

In the early 1970s, RSV was established as causing winter epidemics of acute bronchiolitis [155, 156]. The different clinical spectrum of RSV was recognised [157]. Other respiratory viruses, such as parainfluenza, rhinoviruses, influenza and adenovirus were recognised as other causes [158]. Later, human metapneumovirus was identified as another cause [159]. The relationship of rhinovirus infections to acute exacerbations of asthma was also noted in older children [160]. ICAM-1 is the major receptor for human rhinoviruses [161]. RV infections early in life might predispose to later asthma development [162], but a more probable explanation is that this virus infection may affect persons predisposed to have asthma later in life.

This section offers an overview of the treatment of viralinduced wheeze, both as treatment of a single episode and of recurrent episodes. It has been assumed the majority of episodes will be triggered by a viral cold. Realistically, clinicians treating an acute wheeze will not stratify treatment based on a parent who may be unable to give an objective history of the long-term pattern of wheeze. For outpatient therapy, clinicians and parents have the time to assess that pattern of wheeze and to assign a putative phenotype. For regular therapy, this section separates studies of children with intermittent wheeze from those with interval symptoms between attacks. Such separation has been clearly incorporated into the recent ERS task force on wheezing disorders in preschool children [163].

\section{Treatment of acute viral wheeze}

Stratification of treatment based on wheeze phenotype (i.e. episodic viral wheeze versus multi-trigger wheeze) is assumed to be difficult in the emergency room.

\section{Short-acting $\beta_{2}$-agonists}

Short-acting $\beta_{2}$-agonists are the main treatment for wheeze, both parent-initiated (i.e. in the community) and physician-initiated. 
The evidence for efficacy falls broadly into two categories. First, lung function changes are "objective", but clinical relevance may be unclear. Secondly, there are studies using clinically relevant outcomes in acutely wheezy children. A 2002 Cochrane review sought to determine the effectiveness of $\beta_{2}$-agonists for infants ( $<2$ yrs) with "recurrent or persistent wheeze" [164]. Eight studies meeting the Cochrane criteria were identified [165-172]. Five studies had clinical end-points, and three assessed changes in lung function. Overall, no clear benefit for the use of $\beta_{2}$-agonists was found. The inconsistent benefit of short-acting $\beta_{2}$-agonists has also been seen in studies since 2002 . SKONER et al. [173] found no benefit of parent-given nebulised albuterol/levalbuterol in children aged 2-5 yrs with mild wheeze, in whom the primary outcome was change in caregiver asthma score. In a laboratory setting, however, lung function (specific airway resistance) improved significantly after inhaled salbutamol [174].

The evidence from well-conducted studies that inhaled shortacting $\beta_{2}$-agonists result in clinically relevant outcomes (such as wheeze severity score) in young children $(<2$ yrs $)$ with acute viral wheeze remains weak. Since some beneficial effects of $\beta_{2}$-agonists have been reported for lung function, it is very unlikely that an RCT of inhaled short-acting $\beta_{2}$-agonist therapy in older children with clinically severe wheeze (for either phenotype) will be ethically acceptable, and this approach will remain the cornerstone of acute treatment.

One factor that may underlie the inconsistent results of shortacting $\beta_{2}$-agonist studies in the pre-school age group is a combination of reduced dose delivered to the lower airway, and/or reduced responsiveness to $\beta_{2}$-agonists. Intravenous salbutamol is one way of ensuring that a high concentration of this drug is delivered to the lower airway, albeit with the possibility of increased systemic side-effects. BROWNE et al. [175] assessed $15 \mu \mathrm{g} \cdot \mathrm{kg}^{-1}$ i.v. salbutamol over $10 \mathrm{~min}$ in acutely wheezy children who did not improve after a single dose of nebulised salbutamol: i.v. treated children were ready for discharge $9.7 \mathrm{~h}$ earlier than controls, with no additional sideeffects; responses in the pre-school subgroup were not assessed separately, the majority of children being of school age. Assessing the efficacy of i.v. salbutamol as an adjunct to inhaled $\beta_{2}$-agonist therapy in acutely wheezy pre-school children is ethically acceptable but no trial has addressed this.

\section{Inhaled epinephrine}

Inhaled racemic epinephrine is used for wheeze associated with AVB. A large RCT and a Cochrane review stated that there is insufficient evidence to support the use of epinephrine in the treatment of inpatients with bronchiolitis, but there is some evidence that epinephrine may be favourable to salbutamol and placebo among outpatients [119, 120].

In summary, inhaled epinephrine may have a short-term effect upon symptoms of bronchial obstruction in studies that probably have recruited infants with a mix of "bronchiolitis" (UK definition) and acute viral wheeze (using our criteria). Further studies of nebulised adrenaline should aim to recruit pre-school children aged 1-5 yrs, in whom RSV bronchiolitis (UK definition) can be excluded because of the older age of the children and, perhaps, the lack of widespread chest crackles.

\section{Intermittent high-dose inhaled corticosteroids}

In a systematic review [176], three high-quality studies of intermittent high-dose inhaled corticosteroids for the treatment of the episodic viral wheeze phenotype were identified [177179]. Steroids were started at the onset of the acute episode. Only a modest improvement in symptoms was achieved. DUCHARME et al. [180] found a modest benefit of high-dose fluticasone ( $3 \mathrm{mg}$ beclomethasone dipropionate equivalent) in a 6-12 month RCT of 129 pre-school children with a history of episodic viral wheeze. Fluticasone or placebo was started at the first sign of a cold and continued for up to 10 days. In the active treatment group, $8 \%$ of colds resulted in the need for rescue oral steroids compared with $18 \%$ in the placebo group. Pre-emptive steroid treatment was associated with smaller mean increases in height and weight. No study has assessed the role of high-dose intermittent inhaled corticosteroids in children with interval symptoms and viral-triggered attacks.

\section{Oral corticosteroids}

A trial of parent-initiated oral steroids therapy (PIOST) for intermittent pre-school wheeze, in children who had previously been hospitalised with an attack of acute viral wheeze, found no difference in symptom scores and the number of salbutamol actuations per day [181]. Issuing parents with a course of oral corticosteroids to be given at the first sign of an attack of viral wheeze does not, therefore, appear to be an effective strategy. In contrast, in children aged 6-35 months with acute viral wheeze, oral prednisolone $2 \mathrm{mg} \cdot \mathrm{kg}^{-1} \cdot \mathrm{day}^{-1}$ for 3 days given at presentation to the paediatric emergency department, reduced disease severity, length of hospital stay and the duration of symptoms in those who were subsequently hospitalised [182]. An RCT of 700 children presenting to hospital with acute viral wheeze (most with a history of episodic viral wheeze) found that a short course of prednisolone did not reduce length of stay in hospital or reduce objective measure of wheeze severity [183]. Meta-analysis of data from these studies is, therefore, urgently required in order to answer the question of steroid efficacy in viral wheeze. However, the results of the latest trial suggest there may be little or no benefit for the majority of children with acute viral wheeze. Future studies should assess whether there is a steroid-responsive subgroup.

\section{Leukotriene receptor antagonists}

In a recent study in pre-school children with moderate-tosevere intermittent wheezing, episodic use of either montelukast or budesonide early in respiratory tract illness, when added to albuterol, did not increase the proportion of episodefree days or decrease oral corticosteroid use over a 12-month period. However, indicators of severity of acute illnesses were reduced, particularly in children with positive asthma predictive indices [184].

\section{Regular "prophylactic" treatment}

Inhaled corticosteroids

A systematic review [176] identified only one RCT of regular inhaled corticosteroids for the episodic viral wheeze phenotype in pre-school children. In this study, WILSON et al. [185] compared the effect of 4 months' regular treatment with budesonide $400 \mu \mathrm{g} \cdot$ day $^{-1}$ with placebo and found no difference in symptom score, oral steroid usage or in hospital admission 
between the two groups. KADITIS et al. [186] identified 10 placebo-controlled trials in pre-school children with "persistent" wheezing (377 subjects in total) who received placebo or regular inhaled corticosteroids. Inhaled corticosteroids decreased the symptom score, $\beta_{2}$-agonist use and oral steroid requirement and increased the mean peak expiratory flow rate. Hospitalisation was not reduced. KADITIS et al. [186] concluded that the effects may be clinically trivial. There are major problems with assessing trials that have recruited a "mix" of phenotypes. A Cochrane approach performed by researchers with a detailed knowledge of pre-school wheeze phenotypes is the only way of avoiding bias, but this has not yet been done.

\section{Long-acting $\beta_{2}$-agonists}

Regular inhaled long-acting $\beta_{2}$-agonists (LABAs) in schoolaged children are effective when given with regular inhaled corticosteroids. Bronchodilation with salmeterol is not immediate. Formoterol has a more rapid onset. There are no clinical data for either drug in studies that have recruited only preschool children. In a Cochrane review, Ni CHROININ et al. [187] assessed LABA versus placebo in addition to inhaled corticosteroids in "children and adults with chronic asthma". Eight of the 26 included trials focused on children. The authors concluded "there are insufficient data to make firm conclusions on the use of LABA for pre-school and school-aged children." Evidence that formoterol may achieve prolonged bronchodilation in pre-school children is provided by NIELSEN and BISGAARD [174] who found that it produced sustained bronchodilation for at least $8 \mathrm{~h}$ in pre-school children who were not wheezing at the time of study.

Respiratory function studies support the use of LABA in some pre-school children, but no trial has assessed its use as an "add-on" therapy to inhaled corticosteroids in pre-school asthma using clinically relevant outcomes. By definition, no study has assessed the efficacy of add-on LABA in preventing viral-triggered wheeze attacks in the intermittent wheeze phenotype.

\section{Leukotriene receptor antagonists}

BISGAARD et al. [188] investigated the effect of continuous montelukast therapy on asthma exacerbations in children aged 2-5 yrs, with a history of "intermittent wheezing" and minimal or no interval symptoms. Children were randomised to receive either $4 \mathrm{mg}$ oral montelukast or placebo once a day for 12 months. Montelukast reduced the rate of asthma exacerbations, inhaled corticosteroid and $\beta$-agonist usage, but authors admitted that mild, intermittent symptoms should not be treated daily with montelukast and management should not necessarily involve regular treatment all year round. A study from Australia in children aged 2-14 yrs has suggested that a short course of montelukast, introduced at the first signs of a wheezing episode, results in a modest reduction in healthcare resource utilisation, symptoms, time off from school and parental time off from work in children with intermittent symptoms [189].

In summary, there is some evidence of efficacy of montelukast as monotherapy in episodic viral-wheeze phenotype and possibly for "multi-trigger persistent" pre-school wheeze. Its role as an add-on therapy for pre-school children receiving inhaled corticosteroids is less clear. A significant level of nonresponsiveness has been shown in older children with regular asthma [190, 191], but the frequency of nonresponse has not been reported in young children with wheeze. One should be aware of the recent large randomised placebocontrolled study of montelukast treatment for post-RSV bronchiolitic wheeze (in 979 patients), which showed no effect [192].

\section{Treatment of viral-induced wheeze: summary and recommendations}

Recommendations for treatment of viral-induced wheeze can be found in tables 4 and 5 .

\section{Side-effects}

Medicines used to treat viral induced wheeze are considered safe but some aspects should be kept in mind. The Food and Drug Administration (USA) has warned against the use of inhaled LABA without concomitant anti-inflammatory treatment. Oral corticosteroids have systemic side-effects when used for long or repeated periods of time. Also, high-dose inhaled corticosteroids may affect growth and the hypothalamic-pituitary-adrenal axis.

\section{Conclusions}

The evidence base for treatment of acute viral wheeze and for regular episodic viral wheeze phenotype is weak. Inhaled corticosteroids decrease symptom score, $\beta_{2}$-agonist requirement and oral corticosteroid use, and increase mean peak flow rates in some but not all studies. One problem is that the phenotype is often not clearly described.

\section{Prioritised research questions}

1) Consensus on the definition of pre-school wheeze phenotypes is needed as the basis for clinical trial protocols. Outcomes must be clearly defined.

2) What are the benefits of high-dose inhaled corticosteroids, oral montelukast and i.v. salbutamol for severe acute viralinduced wheeze?

3) What are the benefits of intermittent oral theophylline or intermittent oral montelukast in recurrent wheeze in preschool children?

\section{CROUP}

\section{Treatment of croup: the evidence base}

Viral croup is the most frequent cause of acute upper airway obstruction in children 6 months to 6 yrs of age; parainfluenza viruses types 1 and 3 account for the majority of cases. Croup symptoms are generally short-lived; the majority of children show resolution within 2 days. Most have a mild illness, but pronounced laryngeal obstruction can lead to asynchronous chest wall and abdominal movements, fatigue, hypoxia, hypercapnia and respiratory failure [193]. The mortality rate is very low [194]. Treatment has evolved from mist kettles and tents to the evidence-based practice of corticosteroids and nebulised epinephrine. Very recently, two reviews on the topic were published [195, 196].

\section{Humidified air}

There is a long history of using humidified air (mist therapy) in the treatment of croup. A systematic review of three RCTs 
TABLE 4 Treatment of acute pre-school viral wheeze

\begin{tabular}{|c|c|c|c|}
\hline $\begin{array}{l}\text { Inhaled short-acting } \\
\beta_{2} \text {-agonists }\end{array}$ & $\begin{array}{l}\text { No effect on clinically relevant } \\
\text { outcomes (high), but improvement } \\
\text { of lung function (moderate) }\end{array}$ & $\begin{array}{l}\text { Inhaled short-acting } \beta_{2} \text {-agonists } \\
\text { should be used }\end{array}$ & $\begin{array}{l}\text { Grading applies to children aged }<2 \text { yrs } \\
\text { RCT in older children with acute viral wheeze } \\
\text { unlikely to be done for ethical reasons }\end{array}$ \\
\hline $\begin{array}{l}\text { Intravenous short-acting } \\
\beta_{2} \text {-agonists }\end{array}$ & $\begin{array}{l}\text { No studies in acutely wheezy } \\
\text { pre-school children (very low) }\end{array}$ & $\begin{array}{l}\text { Intravenous short-acting } \beta_{2} \text {-agonists } \\
\text { should not be used }\end{array}$ & No studies in acutely wheezy pre-school children \\
\hline $\begin{array}{l}\text { Inhaled high-dose } \\
\text { corticosteroids } \\
\text { (short course) }\end{array}$ & $\begin{array}{l}\text { Modest effect on clinical outcomes, } \\
\text { when started at the onset of the } \\
\text { acute episode or at the onset of } \\
\text { a cold (moderate) }\end{array}$ & $\begin{array}{l}\text { High-dose intermittent inhaled } \\
\text { corticosteroids should probably } \\
\text { be used on a case-by-case basis, } \\
\text { especially in children with a } \\
\text { positive asthma predictive index }\end{array}$ & $\begin{array}{l}\text { The dose and duration of treatment required to } \\
\text { achieve similar outcomes remain to be clarified }\end{array}$ \\
\hline $\begin{array}{l}\text { Leukotriene receptor } \\
\text { antagonists }\end{array}$ & $\begin{array}{l}\text { Reduction of severity of acute } \\
\text { illnesses (moderate) }\end{array}$ & $\begin{array}{l}\text { Montelukast should probably be } \\
\text { used intermittently on a case-by- } \\
\text { case basis in children with } \\
\text { positive asthma predictive index }\end{array}$ & Heterogeneity of the included phenotypes \\
\hline
\end{tabular}

$\mathrm{RCT}$ : randomised controlled trial.

concluded that, in children with mild-to-moderate croup, there is no evidence that inhalation of humidified air improves the croup score [197]. In another RCT, the effects of $100 \%$ humidified oxygen, $40 \%$ humidified oxygen and standard oxygen (humidity as in ambient room air) were compared in children with moderate-to-severe croup [198]. There were no differences in croup score, treatment with dexamethasone or epinephrine or admission to hospital between the three groups.

\section{Corticosteroids}

There is clear evidence for the effectiveness of steroids, which are now routinely recommended. Meta-analyses of RCTs [199201] have consistently demonstrated significant improvements in patients treated with corticosteroids compared with controls. Corticosteroids decrease the time spent in the emergency room or hospital, the number of return visits and hospital admissions. They also reduce the use of epinephrine, the need for intubation and the risk of reintubation [199-202].

The routes of steroid administration have been extensively investigated. The oral or i.m. routes have been shown to be either equivalent or superior to inhalation [203-206]. The addition of inhaled budesonide to oral dexamethasone was shown to offer no advantage in hospitalised children [207].

Two trials comparing oral and i.m. dexamethasone noted no difference with regard to resolution of croup symptoms, admission to hospital or further treatment [208, 209]. A study comparing i.m. dexamethasone to oral betamethasone also found no difference in reduction of croup score, hospital admission, time to symptom resolution or return for medical care [210]. Two studies compared oral dexamethasone to oral

TABLE 5 Regular preventative therapy for episodic pre-school viral wheeze

\begin{tabular}{llll} 
Medicine & Quality of evidence & Recommendation & Comment \\
\hline Inhaled corticosteroids & $\begin{array}{c}\text { No effect on clinically relevant outcomes } \\
\text { (moderate) } \\
\text { Insufficient evidence in this phenotype } \\
\text { (very low) } \\
\text { Inhaled LABA }\end{array}$ & $\begin{array}{c}\text { Regular inhaled corticosteroids should } \\
\text { probably not be used } \\
\text { Inhaled LABA should not be used }\end{array}$ & $\begin{array}{c}\text { Low number of pre-school children } \\
\text { evaluated }\end{array}$ \\
Montelukast & outcomes (moderate) & Montelukast should probably be used & Only one RCT \\
\end{tabular}

LABA: long-acting $\beta_{2}$-agonist; RCT: randomised controlled trial. 
prednisolone: dexamethasone was found to be superior to prednisolone in reducing rates of return for medical care in one [211]; no difference was noted in reduction of croup score or rates of return for medical care in the other [212]. No studies have directly compared the outcomes of single- and multipledose therapy.

There is conflicting evidence with regard to the effect of dose size of steroids. In a meta-analysis [199], more children admitted to hospital responded to treatment when higher doses of hydrocortisone equivalents were used. A few small RCTs compared different doses of oral dexamethasone and suggested that a dose of $0.15 \mathrm{mg} \cdot \mathrm{kg}^{-1}$ was as efficacious as 0.3 or $0.6 \mathrm{mg} \cdot \mathrm{kg}^{-1}[212-214]$.

The mechanism of action of steroids in croup is not well known. The rapidity of action suggests steroids probably act through vasoconstriction in airway mucosa [215].

\section{Epinephrine}

Nebulised racemic epinephrine has been studied over three decades. Nebulised epinephrine by intermittent positive pressure breathing improves croup scores within $30 \mathrm{~min}$ of treatment but the benefit lasts for $<2$ h $[216,217]$. Epinephrine by nebulisation alone was found to be as effective as nebulisation using intermittent positive pressure breathing [218]. Substantial improvement after treatment with epinephrine has also been shown in five prospective studies investigating various objective measures of severity; the clinical effect

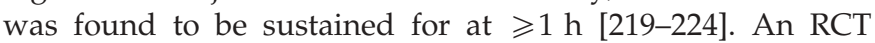
showed L-epinephrine 1:1,000 to be as effective as racemic epinephrine [225].

The effect of epinephrine has been compared with nebulised budesonide in 66 hospitalised children with moderately severe croup; there was no significant difference in efficacy and safety for several outcomes [226].

\section{Heliox}

Theoretically, the administration of a helium-oxygen mixture (heliox) could reduce the degree of respiratory distress as helium, with a lower density than nitrogen, can pass through a narrowed airway with less turbulence. Two RCTs, one comparing heliox to epinephrine in children who had already received i.m. dexamethasone [227], and another comparing heliox to oxygen-enriched air in children with mild croup [228], did not show significant differences in croup scores between the groups. Due to costs and practical limitations, the general use of heliox cannot be recommended.

\section{Other treatments}

Children with croup should be made as comfortable as possible because agitation may cause substantial worsening of symptoms. Children with moderate or severe croup and hypoxia should receive oxygen. Analgesics or antipyretics may be used to reduce fever or discomfort. The use of antitussives, decongestants, antibiotics and $\beta_{2}$-agonists is not indicated.

\section{Treatment of croup: summary and recommendations}

Recommendations for treatment of croup can be found in table 6 .

\section{Side-effects}

Corticosteroids are considered safe in short courses. Concerns exist with respect to their immunosuppressive effects, which might predispose to infectious complications [195, 196]. Nebulised epinephrine has not been associated with major adverse effects [196].

\section{Conclusions}

Corticosteroids are the treatment of choice for children with croup. Benefit is seen at all levels of severity. Nebulised epinephrine is effective for temporary relief of symptoms of airway obstruction and may be used until steroids take effect. Mist therapy has been shown to be ineffective.

\section{Prioritised research questions}

1) To compare the efficacy of a single dose of oral dexamethasone with a single dose of oral prednisolone in children with mild-to-moderate croup.

2) To compare the outcomes of single- versus multiple-dose therapy.

\section{POST-INFECTIOUS BRONCHIOLITIS OBLITERANS Treatment of post-infectious bronchiolitis obliterans: the evidence base}

Bronchiolitis obliterans refers both to histological findings and to a clinical syndrome of airflow obstruction. It is the end stage of a process that begins with bronchiolar epithelial injury followed by an inflammatory reaction which leads to airway obliteration.

Bronchiolitis obliterans is defined histologically by the presence of granulation tissue within small airways and/or

\section{TABLE 6 Treatment of acute viral croup}

\begin{tabular}{|c|c|c|}
\hline Medicine & Quality of evidence & Recommendation \\
\hline Humidified air & Humidified air has no effect on the course of croup (high) & Humidified air should not be used \\
\hline Systemic steroids & Systemic steroids are highly effective on the course of croup (high) & Oral corticosteroids should be used \\
\hline Inhaled steroids & Inhaled steroids are highly effective on the course of croup (high) & $\begin{array}{l}\text { Inhaled steroids should be used (they are not superior to } \\
\text { oral corticosteroids) }\end{array}$ \\
\hline Epinephrine & Nebulised epinephrine is highly effective on the course of croup (high) & $\begin{array}{l}\text { Nebulised epinephrine should be used for temporary } \\
\text { relief of symptoms }\end{array}$ \\
\hline Heliox & Heliox has no effect on the course of croup (moderate) & Heliox should not be used \\
\hline
\end{tabular}


destruction of the small airways by fibrous tissue. The typical pathological changes have a patchy distribution [229].

Respiratory infection is the commonest cause of bronchiolitis obliterans in children (post-infectious bronchiolitis obliterans (PIBO)). Other causes include inhalation of noxious gases, drug toxicity and connective tissue disease [230-234]. It is also seen following lung transplantation where it is referred to as bronchiolitis obliterans syndrome. Infection with adenovirus (particularly serotypes 3, 7 and 21) is by far the most common cause of PIBO. Other infectious agents include respiratory syncytial virus, influenza virus, parainfluenza virus, measles virus, Mycoplasma pneumoniae, Chlamydophylia pneumoniae and Bordatella pertussis [230-233].

The prevalence of PIBO is not known and varies in different parts of the world. In Western Europe it is relatively rare, with most centres only expecting to see one or two cases per year. The prevalence is much higher in some regions of Asia and South America [235].

Swyer-James syndrome (also known as McLeod syndrome) refers to a particular radiographic appearance, in which the disease predominantly affects one lung; the affected lung being smaller, probably as a result of poor lung growth [230]. Histologically and clinically it does not differ from more generalised forms of PIBO.

Infection leading to PIBO typically affects pre-school children and results in a severe acute illness, usually with fever, respiratory distress and an oxygen requirement. Bronchopneumonia is common. Hospital treatment is nearly always required. Mechanical ventilation may be needed and is an independent risk factor for developing PIBO. PIBO is recognised clinically by persistent breathlessness, tachypnoea, hyperinflation, crackles and wheezing, usually with hypoxaemia for $\geqslant 30$ days after the initial infection [229].

Lung function tests show severe airway obstruction that cannot be reversed by inhaled $\beta$-agonists [236]. Pulmonary function in childhood PIBO can deteriorate over time as a consequence of the ongoing inflammatory process [230, 237].

Chest radiograph shows hyperinflation with or without areas of atelectasis and increased interstitial markings. Typical findings on high resolution computed tomography chest scan are patchy areas of hyperinflation giving a mosaic pattern of attenuation. This is best demonstrated by inspiratory and expiratory views, with air trapping becoming more apparent in expiration. There may also be bronchial dilation, bronchial wall thickening, areas of collapse and bronchiectasis [238].

The analysis of the cytological and immunophenotypical profile of bronchoalveolar lavage fluid shows an increase in neutrophils and lymphocytes with a predominance of CD8+ cells [237]. There is a risk of exacerbation with subsequent respiratory tract infections. Long-term follow-up is required. The prognosis remains guarded and death following progressive respiratory failure has been reported.

\section{Treatments that have been tried: anecdotal reports only}

1) Bronchodilators: inhaled $\beta_{2}$-agonists have been used for symptomatic treatment of wheeze. There is often a bronchodilator-responsive component to the fixed airway obstruction.

2) Inhaled corticosteroids: used because they might influence the underlying inflammatory process.

3) Systemic steroids (either oral prednisolone or i.v. pulsed methyl prednisolone): anecdotal evidence of efficacy in severely oxygen-dependent children.

\section{4) Hydroxychloroquine.}

5) i.v. immunoglobulin.

6) Antibiotics: used during infective exacerbations, particularly in children with coexisting bronchiectasis; azithromycin may have benefit as an anti-inflammatory agent as well as an antimicrobial.

7) Oxygen: should be used if hypoxaemia is present.

\section{Treatment of PIBO: summary and recommendations}

Side-effects

None of the treatments have been subjected to systematic assessment of side-effects specific to their use in PIBO.

\section{Conclusions}

PIBO is a heterogeneous disease syndrome based on presentation and histology. No proven effective treatment is available to date.

\section{Prioritised research questions}

1) Define exact aetiopathogenesis of PIBO.

2) Establish disease markers for differential diagnosis.

3) RCTs with large patient numbers and appropriate design.

\section{PAEDIATRIC ILD}

\section{Treatment of paediatric ILD: the evidence base}

ILD in children represents a very heterogeneous group of diseases with a variable natural history. Increasing knowledge of some genetic disorders causing ILD in children, such as surfactant protein deficiencies, is responsible for recent advances in the classification of these disorders. Moreover, the former classifications have not always been based on a systematic and independent analysis of the clinical phenotype, the genetic background, lung function and radiological data, and, most importantly, lung histopathology. A large European study classified ILD at all ages, but lacked a systematic pathological examination [239]. An American study looked at children aged up to two years, with detailed independent pathological review [240], but their data on those aged $>2$ yrs have only been published as an abstract [241]. Thus, there is no uniformly satisfactory classification spanning all ages in children.

We propose the constitution of an international (Europe, USA and Canada) registry with a prospective collection of cases, which should include data on precise clinical phenotype, genetic background, lung and radiological data, and histopathology of lung tissue, with all data being evaluated by independent experts in the field. Such a register has been started in France on a national basis by the group of A. Clement (Centre de référence des maladies respiratoires rares, $\mathrm{CHU}$ 
Hôpital d'Enfants Armand-Trousseau, Paris, France; the French national reference centre for rare diseases). To date, there have been no RCTs in children with ILD. Therefore, we can only extrapolate from adults (where the disease may be different) and report case series. The level of evidence is, thus, wholly unsatisfactory.

\section{ILD of unknown origin}

As lung parenchymal inflammation represents a common feature in these diseases, corticosteroids, such as oral prednisone or pulsed methylprednisolone are usually prescribed, but without any evidence-based recommendations. Case series of reports have shown that methylprednisolone may be effective, even when other steroids fail [242, 243]. Hydroxychloroquine has been used in fibrotic changes on lung histology in some individuals [244-246]. A favourable clinical outcome has been reported with aerosolised reduced glutathione in a child with chronic ILD [247].

\section{ILD of known origin or associated with other diseases}

ILD and connective tissue diseases

Hydroxychloroquine has been used in a 12-yr-old child with lymphocytic interstitial pneumonitis that preceded polyarticular rheumatoid factor positive juvenile arthritis [248]. Other treatments include immunosuppressive agents, such as azathioprine, cyclophosphamide, cyclosporine (most often used in respiratory involvement of juvenile dermatomyositis [249]) or methotrexate [244]. All these immunosuppressants have been used in children with Wegener's granulomatosis [250]. Anti-tumour necrosis factor (anti-TNF)- $\alpha$ therapy [251, 252], bronchoalveolar lavage with diluted surfactant [253], and monthly, high-dose i.v. immunoglobulin therapy have also been used with variable success [254]. Cytosine arabinoside, vincristine and prednisolone, as well as doxorubicin and cyclophosphamide, have been used in patients with Langerhans cell granulomatosis and ILD [255].

\section{Alveolar proteinosis}

This condition is now classified as follows.

1) Surfactant protein deficiency: corticosteroids may enhance the surfactant protein B transcription and are thus generally used in clinical practice without any proven clinical benefit [256].

2) Granulocyte-macrophage colony-stimulating factor (GM$\mathrm{CSF}$ ) receptor issues.

3) GM-CSF auto-antibodies (largely adult disease): a successful treatment with inhaled GM-CSF has been reported in a child with anti-GM-CSF antibodies [257].

4) Macrophage blockade (lymphoma, etc.; largely adult disease): successful treatment of alveolar proteinosis with lung lavage has been reported in children [258-262].

\section{Sarcoidosis}

Because the cause of sarcoidosis is unknown, no specific therapy is available. Corticosteroids are widely used and are often effective. Methylprednisolone pulses have been able to improve lung function in patients with very severe ILD [263]. Inhaled corticosteroids have been used for maintenance treatment in children but in an uncontrolled design and without being able to prevent relapses [264]. Hydroxychloroquine therapy has been used with success in two Australian male children with diffuse pulmonary sarcoidosis [265]. Successful steroid-sparing treatment of severe renal failure secondary to limited renal sarcoidosis was reported in a child treated with mycophenolate mofetil [266]. Anti-TNF- $\alpha$ strategies have also been used in children with sarcoidosis [267, 268].

\section{Eosinophilic pneumonia}

A rapid beneficial response is usually observed after corticosteroids [269].

\section{Idiopathic/infantile pulmonary haemosiderosis}

Corticosteroids and hydroxychloroquine therapy are generally prescribed with variable efficacy [270-273]. Treatment with low-dose cyclophosphamide and azathioprine has also been reported [271, 274, 275].

\section{Desquamative interstitial pneumonia}

A successful clinical response with hydroxychloroquine has been reported [276, 277].

\section{Extrinsic allergic alveolitis}

Avoidance of the allergen is mandatory. Oral or inhaled corticosteroids may be helpful [278-280], as may be pulsed methylprednisolone [281].

\section{Other entities}

Important ILDs which have recently been described include the surfactant protein gene defects $(\mathrm{SpB}, \mathrm{SpC}$ and $A B C A 3)$, neuroendocrine cell hyperplasia of infancy (NEHI) and pulmonary interstitial glycogenosis [282]. Surfactant protein deficiencies are a cause of considerable morbidity and mortality, and there is no known treatment. NEHI gets better without treatment, but the child may have prolonged oxygen dependency in the early years [283]. Pulmonary interstitial glycogenosis generally improves with oral steroids [284]. However, for all three conditions, there is an urgent need for new treatments.

\section{Treatment of paediatric ILD: summary and recommendations}

\section{Side-effects}

The commonest treatments used in paediatric ILD are corticosteroids and immunosuppressives. The side-effects of corticosteroids are hypertension, diabetes and bone demineralisation; for immunosuppressives, such as methotrexate, they are opportunistic infections and bone marrow failure. These patients need the usual careful monitoring.

\section{Conclusions}

ILD is a serious condition in childhood with significant mortality and morbidity. The treatments used have significant and sometimes severe side-effects yet there have been no RCTs to supply evidence to support anything we do. This is a situation in which a pan-European approach is an extremely good way of making progress.

\section{Prioritised research questions}

The constitution of an international register would allow: 1) an improved understanding of the epidemiology of ILD in 
children; 2) an analysis of phenotype-genotype correlations in genetic causes of ILD; and 3) an evaluation by RCTs of the potential treatments, including macrolides.

\section{SUMMARY OF EVIDENCE BASE AND RECOMMENDATIONS FOR FURTHER STUDIES}

The evidence base for considering the use of medicines in respiratory diseases only occurring in children is variable and sometimes absent. In the seven diseases discussed in this report, our knowledge of treatment benefits is virtually nonexistent in the management of congenital lung abnormalities and in PIBO, either as prevention or as treatment. The management of croup is now much more satisfactory and there seems little demand for new clinical trials. Now that ILD in children is better classified, there is a real chance we can begin to develop clinical trials to assess the efficacy and safety of treatment regimes. Because of the relative rarity of these disorders, studies will need to be developed on a European or even a global scale.

The evidence accrued to date and the ensuing knowledge gaps relating to studies needed in BPD, AVB and viral-induced wheeze can be summarised below.

1) To prevent the establishment of BPD, studies are needed to assess the value of iNO, to evaluate the usefulness of inositol and other nutrient supplements, and to investigate the benefit of various antioxidants.

2) To treat BPD once it has been diagnosed, there is value in assessing the effectiveness of surfactant therapy as well as investigating the role of various pulmonary vasodilators.

3) Until an effective vaccine is discovered to universally protect infants from developing AVB, we should focus on clarity and uniformity of definition of this viral infection, undertake separate studies for inpatient and outpatient sufferers due to differing disease severities and fully evaluate therapies such as the use of nebulised hypertonic saline. The potential effect of inhaled corticosteroids and leukotriene receptor antagonists on the development of recurrent respiratory symptoms should also be studied further.

4) Finally, in the more nebulous "viral-induced wheeze" classification, similar well-constructed RCTs with sufficient patient numbers need to be developed to examine the true benefit of high-dose inhaled corticosteroids and the use of leukotriene receptor antagonists in both acute viral wheeze and in recurrent viral wheeze phenotypes.

We must ensure some of these recommendations are taken up by study groups and funding organisations willing to support progression of our understanding of medicines that will have a major impact on the lives of our respiratory paediatric patients.

\section{STATEMENT OF INTEREST}

Statements of interest for W. Lenney, A.L. Boner, L. Bont, A. Bush, K-H. Carlsen, A. Greenough, J. Kimpen and F.M. de Benedictis can be found at www.erj.ersjournals.com/misc/statements.dtl

\section{ACKNOWLEDGEMENTS}

The authors' affiliations are as follows. W. Lenney: Dept of Child Health, University Hospital of North Staffordshire and Keele University, Stoke-on-Trent; A. Bush: Dept of Paediatric Respirology,
National Heart and Lung Institute, Royal Brompton and Imperial College, London; A. Greenough: Dept of Child Health, Kings College Hospital, London; J. Grigg: Academic Unit of Paediatrics, Institute of Cell and Molecular Science, Barts and The London Medical School, London; J. Hull: Dept of Paediatrics, John Radcliffe Hospital, Oxford (all UK). A.L. Boner: Dept of Paediatrics, University of Verona, Verona; F.M. de Benedictis: Dept of Paediatrics, Salesi Childrens Hospital, Ancona (both Italy). L. Bont: Dept of Paediatrics, University Medical Center, Utrecht; J. Kimpen: Wilhelmina Childrens Hospital, Utrecht (both The Netherlands). K-H. Carlsen: Dept of Paediatrics, Rikshospitalet University Hospital, University of Oslo, Oslo (Norway). E. Eber: Paediatric Dept, Medical University of Graz, Graz; M.H. Götz: Dept of Paediatrics and Adolescent Medicine, Wilhelminenhospital, Academic Teaching Hospital, Vienna (both Austria). B. Fauroux: Pneumologie Pédiatrique, Université Pierre et Marie Curie/Hopital Armand Trousseau, Paris (France). M. Sánchez Luna: UCIN, Hospital Materno-Infantil, Madrid (Spain).

F.M. de Benedictis and W. Lenney thank C. Ramacogi (Dept of Paediatrics, Salesi Hospital, Ancona, Italy) and C. Lenney (Nantwich, UK) for secretarial support.

\section{REFERENCES}

1 The GRADE working group. Grading quality of evidence and strength of recommendations. BMJ 2004; 328: 1490-1497.

2 Fujiwara T, Maeta H, Chida S, et al. Artificial surfactant therapy in hyaline-membrane disease. Lancet 1980; 1: 55-59.

3 Soll RF. Synthetic surfactant for respiratory distress syndrome in preterm infants. Cochrane Database Syst Rev 1998; 3: CD001149.

4 Soll RF. Prophylactic synthetic surfactant for preventing morbidity and mortality in preterm infants. Cochrane Database Syst Rev 1998; 2: CD001079.

5 Soll RF. Prophylactic natural surfactant extract for preventing morbidity and mortality in preterm infants. Cochrane Database Syst Rev 1997; 4: CD000511.

6 Soll RF, Blanco F. Natural surfactant extract versus synthetic surfactant for neonatal respiratory distress syndrome. Cochrane Database Syst Rev 2001; 2: CD000144.

7 Soll RF, Morley CJ. Prophylactic versus selective use of surfactant in preventing morbidity and mortality in preterm infants. Cochrane Database Syst Rev 2001; 2: CD000510.

8 Yost CC, Soll RF. Early versus delayed selective surfactant treatment for neonatal respiratory distress syndrome. Cochrane Database Syst Rev 1999; 4: CD001456.

9 Soll RF. Multiple versus single dose natural surfactant extract for severe neonatal respiratory distress syndrome. Cochrane Database Syst Rev 1999; 2: CD000141.

10 Moya F, Gadzinowski J, Bancalari E, et al. A multicenter, randomized, masked, comparison trial of lucinactant, colfosceril palmitate, and beractant for the prevention of respiratory distress syndrome in very preterm infants. Pediatrics 2005; 115: 1018-1029.

11 Sinha S, Lacaze-Masmonteil T, Valls I, et al. A multicenter randomized, controlled trial of lucinactant versus poractant alfa in very premature infants at high risk for respiratory distress syndrome. Pediatrics 2005; 115: 1030-1038.

12 Pfister RH, Soll RF, Wiswell T. Protein containing synthetic surfactant versus animal derived surfactant extract for the prevention and treatment of respiratory distress syndrome. Cochrane Database Syst Rev 2007; 4: CD006069.

13 Long W, Corbet A, Cotton R, et al. American Exosurf Neonatal Study Group 1, and the Canadian Exosurf Neonatal Study Group. A controlled trial of synthetic surfactant in infants weighing $1250 \mathrm{~g}$ or more with respiratory distress syndrome. N Engl J Med 1991; 325: 1696-1703. 
14 Darlow BA, Graham BJ. Vitamin A supplementation to prevent mortality and short and long term morbidity in very low birthweight infants. Cochrane Database Syst Rev 2008; 1: CD000501.

15 Bental RY, Cooper PA, Sandler D, et al. The effects of vitamin A therapy on the incidence of chronic lung disease in premature infants. Pediatr Res 1990; 25: 296A.

16 Papagaroufalis C, Cairis M, Pantazatou E, et al. A trial of vitamin A supplementation in infants susceptible to bronchopulmonary dysplasia. Pediatr Res 1988; 23: 518A.

17 Pearson E, Bose C, Snidow $\mathrm{T}$, et al. Trial of vitamin A supplementation in very low birthweight infants at risk for bronchopulmonary dysplasia. J Pediatr 1992; 121: 420-427.

18 Ravishankar C, Nafday S, Green RS, et al. A trial of vitamin A therapy to facilitate ductal closure in premature infants. J Pediatr 2003; 143: 644-648.

19 Shenai JP, Kennedy KA, Chytil F, et al. Clinical trial of vitamin A supplementation in infants susceptible to bronchopulmonary dysplasia. J Pediatr 1987; 111: 269-277.

20 Ambalavanan N, Tyson JE, Kennedy KA, et al. National Institute of Child Health and Human Development Neonatal Research Network. Vitamin A supplementation for extremely low birth weight infants: outcome at 18 to 22 months. Pediatrics 2005; 115 e249-e254

21 Werkman SH, Peeples JM, Cooke RJ, et al. Effect of vitamin A supplementation of intravenous lipids on early vitamin A intake and status of premature infants. Am J Clin Nutrition 1994; 59: 586-592.

22 Wardle SP, Hughes A, Chen S, et al. Randomised controlled trials of oral vitamin A supplementation in preterm infants to prevent chronic lung disease. Arch Dis Child Fetal Neonatal Ed 2001; 84: F9-F13.

23 Ambalavanan N, Wu T-J, Tyson JE, et al. A comparison of three vitamin A dosing regimens in extremely low birthweight infants. J Pediatr 2003; 142: 656-661.

24 Halliday HL, Ehrenkranz RA, Doyle LW. Early postnatal ( $<96$ hours) corticosteroids for preventing chronic lung disease in preterm infants. Cochrane Database Syst Rev 2003; 1: CD001146.

25 Halliday HL, Ehrenkranz RA, Doyle LW. Moderately early (7-14 days) postnatal corticosteroids for preventing chronic lung disease in preterm infants. Cochrane Database Syst Rev 2003; 1: CD001144

26 Doyle LW, Halliday HL, Ehrenkranz RA, et al. Impact of postnatal systemic corticosteroids on mortality and cerebral palsy in preterm infants: effect modification by risk for chronic lung disease. Pediatrics 2005; 115: 655-661.

27 Doyle LW, Davis PG, Morley CJ, et al. Low dose dexamethasone facilitates extubation among chronically ventilator dependent infants: a multicentre, international, randomized controlled trial. Pediatrics 2006; 117: 75-83.

28 Doyle LW, Davis PG, Morley CJ, et al. Outcome at two years of age of infants from the DART study: a multicentre, international, randomized controlled trial of low dose dexamethasone. Pediatrics 2007; 119: 716-721.

29 Watterberg KL, Gerdes JS, Gifford KL, et al. Prophylaxis against early adrenal insufficiency to prevent chronic lung disease in premature infants. Pediatrics 1999; 104: 1258-1263.

30 Watterberg KL, Gerdes JS, Cole CH, et al. Prophylaxis of early adrenal insufficiency to prevent bronchopulmonary dysplasia: a multicenter trial. Pediatrics 2004; 114: 1649-1657.

31 Bonsante F, Latorre G, Iacobelli S, et al. Early low dose hydrocortisone in very preterm infants: a randomized, placebocontrolled trial. Neonatology 2007; 91: 217-221.

32 Shah SS, Ohlsson A, Halliday H, et al. Early administration of inhaled corticosteroids for preventing chronic lung disease in ventilated very low birthweight preterm infants. Cochrane Database Syst Rev 2007; 4: CD001969.
33 Finer NN, Barrington KJ. Nitric oxide for respiratory failure in infants born at or near term. Cochrane Database Syst Rev 2006; 4: CD000399.

34 Hogman $M$, Frostell C, Arnberg $\mathrm{H}$, et al. Bleeding time prolongation and nitric oxide inhalation. Lancet 1993; 341: 1664-1665.

35 Cheung PY, Salas E, Etches PC, et al. Inhaled nitric oxide and inhibition of platelet aggregation in critically ill neonates. Lancet 1998; 351: 1181-1182.

36 Van Meurs KP, Rhine WD, Asselin JM, et al. Preemie NO Collaborative Group. Response of premature infants with severe respiratory failure to inhaled nitric oxide. Pediatr Pulmonol 1997; 24: $319-323$

37 Barrington KJ, Finer NN. Inhaled nitric oxide for preterm infants. A systematic review. Pediatrics 2007; 120: 1088-1099.

38 Ballard RA, Truog WE, Cnaan A, et al. Inhaled nitric oxide in preterm infants undergoing mechanical ventilation. $N$ Engl J Med 2006; 355: 343-353.

39 Mestan KKL, Marks JD, Hecox K, et al. Neurodevelopmental outcome of premature infants treated with inhaled nitric oxide. N Engl J Med 2005; 352: 23-32.

40 Tanaka Y, Hayashi T, Kitajima H, et al. Inhaled nitric oxide therapy decreases the risk of cerebral palsy in preterm infants with persistent pulmonary hypertension of the newborn. Pediatrics 2007; 119: 1159-1164.

41 Kinsella JP, Parker TA, Galan H, et al. Effects of inhaled nitric oxide on pulmonary edema and lung neutrophil accumulation in severe experimental hyaline membrane disease. Pediatr Res 1997; 41: 457-463.

42 Hallman M. Molecular interactions between nitric oxide and lung surfactant. Biol Neonate 1997; 71: 44-48.

43 Schreiber MD, Gin-Mestran K, Marks JD, et al. Inhaled nitric oxide in premature infants with respiratory distress syndrome. N Engl J Med 2003; 349: 2099-2107.

44 Kinsella JP, Cutter GR, Walsh WF, et al. Early inhaled nitric oxide therapy in premature newborns with respiratory failure. $N$ Engl J Med 2006; 355: 354-364.

45 Howlett A, Ohlsson A. Inositol for respiratory distress syndrome in preterm infants. Cochrane Database Syst Rev 2003; 4: CD000366.

$46 \mathrm{Ng}$ GY, da Silva O, Ohlsson A. Bronchodilators for the prevention and treatment of chronic lung disease in preterm infants. Cochrane Database Syst Rev 2001; 2: CD003214.

$47 \mathrm{Ng} \mathrm{GY,} \mathrm{Ohlsson} \mathrm{A.} \mathrm{Cromolyn} \mathrm{sodium} \mathrm{for} \mathrm{the} \mathrm{prevention} \mathrm{of}$ chronic lung disease in preterm infants. Cochrane Database Syst Rev 2001; 1: CD003059.

48 Wang EEL, Ohlsson A, Kellner JD. Association of Ureaplasma urealyticum colonization with chronic lung disease of prematurity: results of a meta-analysis. J Pediatr 1995; 127: 640-644.

49 Mabanta CG, Pryhuber GS, Weinberg GA, et al. Erythromycin for the prevention of chronic lung disease in intubated preterm infants at risk for, or colonized or infected with Ureaplasma urealyticum. Cochrane Database Syst Rev 2003; 4: CD003744.

50 Baier RJ, Loggins J, Kruger TE. Failure of erythromycin to eliminate airway colonization with Ureaplasma urealyticum in very low birth weight infants. BMC Pediatr 2003; 3: 10 .

51 Ballard HO, Bernard P, Qualls J, et al. Azithromycin protects against hyperoxic lung injury in neonatal rats. J Invest Med 2007; 55: 299-305.

52 Aghai ZH, Kode A, Saslow JG, et al. Azithromycin suppresses activation of nuclear factor- $\mathrm{\kappa B}$ and synthesis of pro-inflammatory cytokines in tracheal aspirate cells from premature infants. Pediatr Res 2007; 62: 483-488.

53 Ballard HO, Anstead MI, Shook LA. Azithromycin in the extremely low birth weight infant for the prevention of bronchopulmonary dysplasia: a pilot study. Respir Res 2007; 8: 41. 
54 Padmanabhan R, Gudapaty R, Liener I, et al. Protection against pulmonary oxygen toxicity in rats by the intratracheal administration of liposome-encapsulated superoxide dismutase or catalase. Am J Respir Dis 1985; 132: 164-167.

55 Davis JM, Rosenfeld W, Richter SE, et al. Safety and pharmacokinetics of multiple doses of recombinant human CuZn superoxide dismutase administered intratracheally to premature neonates with respiratory distress syndrome. Pediatrics 1997; 100: 24-30.

56 Davis JM, Parad RB, Michele T, et al. Pulmonary outcome at 1 year corrected age in premature infants treated at birth with recombinant human CuZn superoxide dismutase. Pediatrics 2003; 111: 469-476.

57 Ahola $\mathrm{T}$, Lapatto R, Raivio KO, et al. $\mathrm{N}$-acetylcysteine does not prevent bronchopulmonary dysplasia in immature infants: a randomized controlled trial. J Pediatr 2003; 143: 713-719.

58 Sandberg K, Fellman V, Stigson L, et al. N-acetylcysteine administration during the first week of life does not improve lung function in extremely low birth weight infants. Biol Neonate 2004; 86: 275-279.

59 Russell GA, Cooke RW. Randomised controlled trial of allopurinol prophylaxis in very preterm infants. Arch Dis Child Fetal Neonatal Ed 1995; 73: F27-F31.

60 Rodriguez C, Mayo JC, Sainz RM, et al. Regulation of antioxidant enzymes: a significant role for melatonin. J Pineal Res 2004; 36: 1-9.

61 Gitto E, Reiter RJ, Sabatino G, et al. Correlation among cytokines, bronchopulmonary dysplasia and modality of ventilation in preterm newborns: improvement with melatonin treatment. J Pineal Res 2005; 39: 287-293.

62 Brion LP, Bell EF, Raghuveer TS. Vitamin E supplementation for prevention of morbidity and mortality in preterm infants. Cochrane Database Syst Rev 2003; 4: CD003665.

63 Hazinski TA, France M, Kennedy KA, et al. Cimetidine reduces hyperoxic lung injury in lambs. J Appl Physiol 1989; 67: 2586-2592.

64 Cotton RB, Hazinski TA, Morrow JD, et al. Cimetidine does not prevent lung injury in newborn premature infants. Pediatr Res 2006; 59: 795-800.

65 Schmidt B, Roberts RS, Davis P, et al. Caffeine therapy for apnea of prematurity. N Engl J Med 2006; 354: 2112-2121.

66 Schmidt B, Roberts RS, Davis P, et al. Long term effects of caffeine therapy for apnea of prematurity. N Engl J Med 2007; 357: 1893-1902.

67 Little S, Dean T, Bevin S, et al. Role of elevated plasma soluble ICAM-1 and bronchial lavage fluid IL-8 levels as markers of chronic lung disease in premature infants. Thorax 1995; 50: 1073-1079.

68 ter Horst SA, Wagenaar GT, de Boer E, et al. Pentoxifylline reduces fibrin deposition and prolongs survival in neonatal hyperoxic lung injury. J Appl Physiol 2004; 97: 2014-2019.

69 Lauterbach R, Szymura-Oleksiak J. Nebulized pentoxifylline in successful treatment of five premature neonates with bronchopulmonary dysplasia. Eur J Pediatr 1999; 158: 607.

70 Lauterbach R, Szymura-Oleksiak J, Pawlik D, et al. Nebulised pentoxifylline for prevention of bronchopulmonary dysplasia in very low birthweight infants: a pilot clinical study. J Matern Fetal Neonatal Med 2006; 19: 433-448.

71 Massaro GD, Mortola JP, Massaro D. Estrogen modulates the dimensions of the lung's gas exchange surface area and alveoli in female rats. Am J Physiol 1996; 270: L110-L114.

72 Trotter A, Ebsen M, Kiossis E, et al. Prenatal estrogen and progesterone deprivation impairs alveolar formation and fluid clearance in newborn piglets. Pediatr Res 2006; 60: 60-64.

73 Trotter A, Maier L, Kron M, et al. Effect of oestradiol and progesterone replacement on bronchopulmonary dysplasia in extremely preterm infants. Arch Dis Child Fetal Neonatal Ed 2007; 92: F94-F98.
74 Moya MP, Gow AJ, McMahon TJ, et al. S-nitrosothiol repletion by an inhaled gas regulates pulmonary function. Proc Nat Acad Sci USA 2001; 98: 5792-5797.

75 Auten RL, Mason SN, Whorton MH, et al. Inhaled ethyl nitrate prevents hyperoxia impaired postnatal alveolar development in newborn rats. Am J Respir Crit Care Med 2007; 176: 291-299.

76 Merrill JD, Ballard RA, Cnaan A, et al. Dysfunction of pulmonary surfactant in chronically ventilated premature infants. Pediatr Res 2004; 56: 918-926.

77 Cogo PE, Zimmermann LJ, Pesavento R, et al. Surfactant kinetics in preterm infants on mechanical ventilation who did and did not develop bronchopulmonary dysplasia. Crit Care Med 2003; 31: 1532-1538.

78 Pandit PB, Dunn MS, Kelly EN, et al. Surfactant replacement in neonates with early chronic lung disease. Pediatrics 1995; 95 851-854.

79 Katz LA, Klein JM. Repeat surfactant therapy for postsurfactant slump. J Perinatol 2006; 26: 414-422.

80 Halliday HL, Ehrenkranz RA, Doyle LW. Delayed ( $>3$ weeks) postnatal corticosteroids for chronic lung disease in preterm infants. Cochrane Database Syst Rev 2003; 1: CD001145.

81 Brion LP, Primhak RA. Intravenous or enteral loop diuretics for preterm infants with (or developing) chronic lung disease. Cochrane Database Syst Rev 2000; 4: CD001453.

82 Brion LP, Primhak RA, Ambrosio-Perez I. Diuretics acting on the distal renal tubule for preterm infants with (or developing) chronic lung disease. Cochrane Database Syst Rev 2002; 1: CD001817.

83 Brion LP, Primhak RA, Yong W. Aerosolized diuretics for preterm infants with (or developing) chronic lung disease. Cochrane Database Syst Rev 2006; 2: CD001694.

84 Najak ZD, Harris EM, Lazzara A, et al. Pulmonary effects of furosemide in preterm infants with lung disease. J Pediatr 1983; 102: 758-763.

85 McCann EM, Lewis K, Deming DD, et al. Controlled trial of furosemide therapy in infants with chronic lung disease. J Pediatr 1985; 106: 957-962.

86 Singhal N, McMilan DD, Rademaker AW. Furosemide improves lung compliance in infants with bronchopulmonary dysplasia. Pediatr Res 1983; 17: 336A.

87 Rush MG, Engelhardt B, Parker RA, et al. Double-blind placebocontrolled trial of alternate day furosemide therapy in infants with chronic bronchopulmonary dysplasia. J Pediatr 1990; 117: 112-118.

88 Reiter PD, Makhlouf R, Stiles AD. Comparison of 6-hour infusion versus bolus furosemide in premature infants. Pharmacotherapy 1998; 18: 63-68.

89 Albersheim S, Solimano A, Sharma AK, et al. Randomized double-blind, controlled trial of long term diuretic therapy for bronchopulmonary dysplasia. J Pediatr 1989; 115: 615-620.

90 Engelhart B, Blalock WA, DonLevy S, et al. Effect of spironolactone-hydrochlorothiazide on lung function in infants with chronic bronchopulmonary dysplasia. J Pediatr 1989; 114: 619-624.

91 Kao LC, Durand DJ, McCrea RC, et al. Randomised trial of long term diuretic therapy for infants with oxygen dependent bronchopulmonary dysplasia. J Pediatr 1994; 124: 772-781.

92 Kao LC, Warburton D, Cheng MH, et al. Effect of oral diuretics on pulmonary mechanics in infants with chronic bronchopulmonary dysplasia. Results of a double-blind crossover sequential trial. Pediatrics 1984; 74: 37-44.

93 Hoffman DJ, Gerdes JS, Abbasi S. Pulmonary function and electrolyte balance following spironalactone treatment in preterm infants with chronic lung disease. A double-blind, placebocontrolled, randomized trial. J Perinatol 2000; 20: 41-45.

94 Segar JL, Chemtob S, Bell EF. Changes in body water compartments with diuretic therapy in infants with chronic lung disease. Early Hum Dev 1997; 48: 99-107. 
95 Cabal LA, Larrazabal C, Ramanathan R, et al. Effects of metaproterenol on pulmonary mechanics, oxygenation and ventilation in infants with chronic lung disease. J Pediatr 1987; 110: 116-119.

96 Denjean A, Guimaraes H, Migdal M, et al. Dose-related bronchodilator response to aerosolized salbutamol (albuterol) in ventilatordependent premature infants. J Pediatr 1992; 120: 974-979.

97 Wilkie RA, Bryan MH. Effect of bronchodilators on airway resistance in ventilator-dependent neonates with chronic lung disease. J Pediatr 1987; 111: 278-282.

98 Kao LC, Durand DJ, Nickerson BG. Effects of inhaled metaproterenol and atropine on the pulmonary mechanics of infants with bronchopulmonary dysplasia. Pediatr Pulmonol 1989; 6: 74-80.

99 Abman S, Sondheimer H. Pulmonary circulation and cardiovascular sequelae of BPD. In: Weir EK, Archer SL, Reeves JT, eds. Diagnosis and Treatment of Pulmonary Hypertension. New York, Futura, 1992; pp. 155-180.

100 Goodman G, Perkin RM, Anas NG, et al. Pulmonary hypertension in infants with bronchopulmonary dysplasia. J Pediatr 1988; 112: $67-72$.

101 Walther FJ, Bendes FJ, Leighton JO. Persistent pulmonary hypertension in premature neonates with severe respiratory distress syndrome. Pediatrics 1992; 90: 899-904.

102 Stenmark KR, Abman SH. Lung vascular development: Implications for the pathogenesis of bronchopulmonary dysplasia. Annu Rev Physiol 2005; 67: 623-661.

103 Kasian GF, Ninan A, Duncan WJ, et al. Treatment of pulmonary hypertension with diltiazem in a child with bronchopulmonary dysplasia. Can J Cardiol 1988; 4: 181-184.

104 Rugulotto S, Errico G, Beghini R, et al. Weaning of epoprostenol in a small infant receiving concomitant bosentan for severe pulmonary arterial hypertension secondary to bronchopulmonary dysplasia. Minerva Pediatr 2006; 58: 491-494.

105 Bush A, Busst CM, Knight WB. Changes in pulmonary circulation in severe bronchopulmonary dysplasia. Arch Dis Child 1990; 65: 739-745.

106 Hon KL, Cheung KL, Siu KL, et al. Oral sildenafil for treatment of severe pulmonary hypertension in an infant. Biol Neonate 2005; 88: 109-112.

107 Jonson CE, Beekman RH, Kostyshak DA. Pharmacokinetics and pharmacodynamics of nifedipine in children with bronchopulmonary dysplasia and pulmonary hypertension. Pediatr Res 1991; 29: 500-503

108 Brownlee JR, Beekman RH, Rosenthal A. Acute hemodynamic effects of nifedipine in infants with bronchopulmonary dysplasia and pulmonary hypertension. Pediatr Res 1988; 24: 186-190.

109 Banks BA, Seri I, Ischiropoulos $\mathrm{H}$, et al. Changes in oxygenation with inhaled nitric oxide in severe bronchopulmonary dysplasia. Pediatrics 1999; 103: 610-618.

110 Tsao K, Hawgood S, Vu L, et al. Resolution of hydrops fetalis in congenital cystic adenomatoid malformation after prenatal steroid therapy. J Pediatr Surg 2003; 38: 508-510.

111 Peranteau WH, Wilson RD, Liechty KW, et al. Effect of maternal betamethasone administration on prenatal congenital cystic adenomatoid malformation growth and fetal survival. Fetal Diagn Ther 2007; 22: 365-371.

112 Leung WC, Ngai C, Lam TP, et al. Unexpected intrauterine death following resolution of hydrops fetalis after betamethasone treatment in a fetus with a large cystic adenomatoid malformation of the lung. Ultrasound Obstet Gynecol 2005; 25: 610-612.

113 Smyth RL, Openshaw PJ. Bronchiolitis. Lancet 2006; 368: 312-322.

114 McDonald NE, Hall CB, Suffin SC, et al. Respiratory syncytial virus infection in infants with congenital heart disease. N Engl J Med 1982; 307: 397-400.

115 Bont L, Kimpen JL. Immunological mechanisms of severe respiratory syncytial virus bronchiolitis. Intensive Care Med 2002; 28: 616-621.
116 Bloemers BL, van Furth AM, Weijerman ME, et al. Down syndrome: a novel risk factor for respiratory syncytial virus bronchiolitis - a prospective birth-cohort study. Pediatrics 2007; 120: e1076-e1081.

117 Simoes EAF. Respiratory syncytial virus infection. Lancet 1999; 354: 847-852.

118 Gadomski AM, Bhasale AL. Bronchodilators for bronchiolitis. Cochrane Database Syst Rev 2006; 3: CD001266.

119 Wainwright C, Altamirano L, Cheney M, et al. A multicenter, randomized, double-blind, controlled trial of nebulized epinephrine in infants with acute bronchiolitis. N Engl J Med 2003; 349: 27-35.

120 Hartling L, Wiebe N, Russell K, et al. Epinephrine for bronchiolitis. Cochrane Database Syst Rev 2004; 1: CD003123.

121 American Academy of Pediatrics. Diagnosis and management of bronchiolitis. Pediatrics 2006; 118: 1774-1793.

122 Kimpen JL. Management of respiratory syncytial virus infection. Curr Opin Infect Dis 2001; 14: 323-328.

123 Barben J, Kuehni CE, Trachsel D, et al. Management of acute bronchiolitis: can evidence based guidelines alter clinical practice? Thorax 2008; 63: 1103-1109.

124 Richter H, Seddon P. Early nebulized budesonide in the treatment of bronchiolitis and the prevention of postbronchiolitic wheezing. J Pediatr 1998; 132: 849-853.

125 Cade A, Brownlee KG, Conway SP, et al. Randomised placebo controlled trial of nebulised corticosteroids in acute respiratory syncytial viral bronchiolitis. Arch Dis Child 2000; 82: 126-130.

126 Bentur L, Shoseyov D, Feigenbaum D, et al. Dexamethasone inhalations in RSV bronchiolitis: a double-blind, placebocontrolled study. Acta Paediatr 2005; 94: 866-871.

127 Bisgaard $\mathrm{H}$, Hermansen MN, Loland L, et al. Intermittent inhaled corticosteroids in infants with episodic wheezing. $N$ Engl J Med 2006; 354: 1998-2005.

128 Blom D, Ermers M, Bont L, et al. Inhaled corticosteroids during acute bronchiolitis in the prevention of post-bronchiolitic wheezing. Cochrane Database Syst Rev 2007; 1: CD004881.

129 Patel H, Platt R, Lozano JM, et al. Glucocorticoids for acute viral bronchiolitis in infants and young children. Cochrane Database Syst Rev 2004; 3: CD004878.

130 Teeratakulpisarn J, Limwattananon C, Tanupattarachai S, et al. Efficacy of dexamethasone injection for acute bronchiolitis in hospitalized children: a randomized, double-blind, placebocontrolled trial. Pediatr Pulmonol 2007; 42: 433-439.

131 Corneli HM, Zorc JJ, Majahan P, et al. A multicenter, randomized, controlled trial of dexamethasone for bronchiolitis. $N$ Engl J Med 2007; 357: 331-339.

132 van Woensel JB, van Aalderen $\mathrm{WM}$, de Weerd $\mathrm{W}$, et al. Dexamethasone for treatment of patients mechanically ventilated for lower respiratory tract infection caused by respiratory syncytial virus. Thorax 2003; 58: 383-387.

133 Da Dalt L, Callegaro S, Carraro S, et al. Nasal lavage leukotrienes in infants with RSV bronchiolitis. Pediatr Allergy Immunol 2007; 18: 100-104.

134 Amirav I, Luder AS, Kruger N, et al. A double-blind, placebocontrolled, randomized trial of montelukast for acute bronchiolitis. Pediatrics 2008; 122: e1249-e1255.

135 Bisgaard H. Montelukast in RSV-bronchiolitis. Am J Respir Crit Care Med 2004; 169: 542-543.

136 Bisgaard H, Flores-Nunez A, Goh A, et al. Study of montelukast for the treatment of post-respiratory syncytial virus bronchiolitis in children. Am J Respir Crit Care Med 2008; 178: 854-860.

137 Fuller H, Del Mar C. Immunoglobulin treatment for respiratory syncytial virus infection. Cochrane Database Syst Rev 2006; 4: CD004883.

138 The Impact Study Group. Palimivumab reduces hospitalisation from respiratory syncytial virus infection in high risk infants. Pediatrics 1998; 102: 531-537. 
139 Bloomfield P, Dalton D, Karleka A, et al. Bacteraemia and antibiotic use in respiratory syncytial virus infections. Arch Dis Child 2004; 89: 363-367.

140 Field CM, Connolly JH, Murtagh G, et al. Antibiotic treatment of epidemic bronchiolitis- a double-blind trial. Br Med J 1966; 1: 83-85.

141 Tahan F, Ozcan A, Koc N. Clarithromycin in the treatment of RSV bronchiolitis: a double-blind, randomised, placebo-controlled trial. Eur Respir J 2007; 29: 91-97.

142 Kneyber MC, van Woensel JB, Uijtendaal E, et al. Azithromycin does not improve disease course in hospitalized infants with respiratory syncytial virus (RSV) lower respiratory tract disease: a randomized equivalence trial. Pediatr Pulmonol 2008; 43: 142-149.

143 Ventre K, Randolph A. Ribavirin for respiratory syncytial virus infection of the lower respiratory tract in infants and young children. Cochrane Database Syst Rev 2004; 4: CD000181.

144 King VJ, Viswanathan M, Bordley WC, et al. Pharmacologic treatment of bronchiolitis in infants and children: a systematic review. Arch Pediatr Adolesc Med 2004; 158: 127-137.

145 Perrotta C, Ortiz Z, Roque M. Chest physiotherapy for acute bronchiolitis in paediatric patients between 0 and 24 months old. Cochrane Database Syst Rev 2007; 1: CD004873.

146 Sarrell EM, Tal G, Witzling M, et al. Nebulized 3\% hypertonic saline solution treatment in ambulatory children with viral bronchiolitis decreases symptoms. Chest 2002; 122: 2015-2020.

147 Mandelberg A, Tal G, Witzling M, et al. Nebulized 3\% hypertonic saline solution treatment in hospitalized infants with viral bronchiolitis. Chest 2003; 123: 481-487.

148 Kuzik BA, Al-Qadhi SA, Kent S, et al. Nebulized hypertonic saline in the treatment of viral bronchiolitis in infants. J Pediatr 2007; 151: 266-270.

149 Fitzgerald DA, Kilham HA. Bronchiolitis: assessment and evidence-based management. Med J Aust 2004; 180: 399-404.

150 Grigg J, Silverman M. Wheezing disorders in young children: one disease or several phenotypes? In: Frey U, Gerritsen J, eds. Respiratory Diseases in Infants and Children. Eur Respir Mon 2006; 37: 153-169.

151 Carlsen KH. What distinguishes the asthmatic amongst the infant wheezers? Pediatr Allergy Immunol 1997; 8: s40-s45.

152 Spycher BD, Silverman M, Brooke AM, et al. Distinguishing phenotypes of childhood wheeze and cough using latent class analysis. Eur Respir J 2008; 31: 974-981.

153 Corneli HM, Zorc JJ, Majahan P, et al. A multicenter, randomized, controlled trial of dexamethasone for bronchiolitis. $N$ Engl J Med 2007; 357: 331-339.

154 Stafler P. Dexamethasone for bronchiolitis. N Engl J Med 2007; 357: 1659-1660.

155 Parrott RH, Kim HW, Arrobio JO, et al. Epidemiology of respiratory syncytial virus infection in Washington, DC. II. Infection and disease with respect to age, immunologic status, race and sex. Am J Epidemiol 1973; 98: 289-300.

156 McIntosh K, Ellis EF, Hoffman LS, et al. Association of viral and bacterial respiratory infection with exacerbations of wheezing in young asthmatic children. J Pediatr 1973; 82: 578-590.

157 Carlsen $\mathrm{KH}$, Orstavik I, Halvorsen K. Viral infections of the respiratory tract in hospitalized children. A study from Oslo during a 90 months' period. Acta Paediatr Scand 1983; 72: 53-58.

158 Carlsen KH, Orstavik I. Bronchopulmonary obstruction in children with respiratory virus infections. Eur J Respir Dis 1984; 65: 92-98.

159 van den Hoogen BG, de Jong JC, Groen J, et al. A newly discovered human pneumovirus isolated from young children with respiratory tract disease. Nat Med 2001; 7: 719-724.

160 Johnston SL, Pattemore PK, Sanderson G, et al. Community study of role of viral infections in exacerbations of asthma in 9-11 year old children. BMJ 1995; 310: 1225-1229.

161 Greve JM, Davis G, Meyer AM, et al. The major human rhinovirus receptor is ICAM-1. Cell 1989; 56: 839-847.
162 Lemanske RF Jr, Jackson DJ, Gangnon RE, et al. Rhinovirus illnesses during infancy predict subsequent childhood wheezing. J Allergy Clin Immunol 2005; 116: 571-577.

163 Brand PL, Baraldi E, Bisgaard H, et al. Definition, assessment and treatment of wheezing disorders in preschool children: an evidence-based approach. Eur Respir J 2008; 32: 1096-1110.

164 Chavasse R, Seddon P, Bara A, et al. Short acting $\beta$-agonists for recurrent wheeze in children under 2 years of age. Cochrane Database Syst Rev 2002; 3: CD002873.

165 Prahl P, Petersen NT, Hornsleth A. $\beta_{2}$-agonists for the treatment of wheezy bronchitis? Ann Allergy 1986; 57: 439-441.

166 Prendiville A, Green S, Silverman M. Airway responsiveness in wheezy infants: evidence for functional $\beta$-adrenergic receptors. Thorax 1987; 42: 100-104.

167 Kraemer R, Frey U, Sommer CW, et al. Short-term effect of albuterol, delivered via a new auxiliary device, in wheezy infants. Am Rev Respir Dis 1991; 144: 347-351.

168 Bentur L, Canny GJ, Shields MD, et al. Controlled trial of nebulized albuterol in children younger than 2 years of age with acute asthma. Pediatrics 1992; 89: 133-137.

169 Clarke JR, Aston H, Silverman M. Delivery of salbutamol by metered dose inhaler and valved spacer to wheezy infants: effect on bronchial responsiveness. Arch Dis Child 1993; 69: 125-129.

170 Fox GF, Marsh MJ, Milner AD. Treatment of recurrent acute wheezing episodes in infancy with oral salbutamol and prednisolone. Eur J Pediatr 1996; 155: 512-516.

171 Kraemer R, Graf Bigler U, Casaulta Aebischer C, et al. Clinical and physiological improvement after inhalation of low-dose beclomethasone dipropionate and salbutamol in wheezy infants. Respiration 1997; 64: 342-349.

172 Chavasse RJ, Bastian-Lee Y, Richter H, et al. Inhaled salbutamol for wheezy infants: a randomised controlled trial. Arch Dis Child 2000; 82: 370-375.

173 Skoner DP, Greos LS, Kim KT, et al. Evaluation of the safety and efficacy of levalbuterol in 2-5-year-old patients with asthma. Pediatr Pulmonol 2005; 40: 477-486.

174 Nielsen KG, Bisgaard H. Bronchodilation and bronchoprotection in asthmatic preschool children from formoterol administered by mechanically actuated dry-powder inhaler and spacer. Am J Respir Crit Care Med 2001; 164: 256-259.

175 Browne GJ, Penna AS, Phung X, et al. Randomised trial of intravenous salbutamol in early management of acute severe asthma in children. Lancet 1997; 349: 301-305.

176 Panickar JR, Grigg J. Controversies in the management of preschool viral wheeze. Paediatr Respir Rev 2006; 7: 293-298.

177 Wilson NM, Silverman M. Treatment of acute, episodic asthma in preschool children using intermittent high dose inhaled steroids at home. Arch Dis Child 1990; 65: 407-410.

178 Connett G, Lenney W. Prevention of viral induced asthma attacks using inhaled budesonide. Arch Dis Child 1993; 68: 85-87.

179 Svedmyr J, Nyberg E, Asbrink-Nilsson E, et al. Intermittent treatment with inhaled steroids for deterioration of asthma due to upper respiratory tract infections. Acta Paediatr 1995; 84: 884-888

180 Ducharme FM, Lemire C, Noya FJ, et al. Preemptive use of highdose fluticasone for virus-induced wheezing in young children. N Engl J Med 2009; 360: 339-353.

181 Oommen A, Lambert PC, Grigg J. Efficacy of a short course of parent-initiated oral prednisolone for viral wheeze in children aged 1-5 years: randomised controlled trial. Lancet 2003; 362: 1433-1438.

182 Csonka $\mathrm{P}$, Kaila M, Laippala $\mathrm{P}$, et al. Oral prednisolone in the acute management of children age 6 to 35 months with viral respiratory infection-induced lower airway disease: a randomized, placebo-controlled trial. J Pediatr 2003; 143: 725-730.

183 Panickar J, Lakhanpaul M, Lambert PC, et al. Oral prednisolone for preschool children with acute virus-induced wheezing. N Engl J Med 2009; 360: 329-338. 
184 Bacharier LB, Phillips BR, Zeiger RS, et al. Episodic use of an inhaled corticosteroid or leukotriene receptor antagonist in preschool children with moderate-to-severe intermittent wheezing. J Allergy Clin Immunol 2008; 122: 1127-1135.

185 Wilson N, Sloper K, Silverman M. Effect of continuous treatment with topical corticosteroid on episodic viral wheeze in preschool children. Arch Dis Child 1995; 72: 317-320.

186 Kaditis AG, Winnie G, Syrogiannopoulos GA. Anti-inflammatory pharmacotherapy for wheezing in preschool children. Pediatr Pulmonol 2007; 42: 407-420.

$187 \mathrm{Ni}$ Chroinin M, Greenstone IR, Danish A, et al. Long-acting $\beta_{2-}$ agonists versus placebo in addition to inhaled corticosteroids in children and adults with chronic asthma. Cochrane Database Syst Rev 2005; 4: CD005535.

188 Bisgaard H, Zielen S, Garcia-Garcia ML, et al. Montelukast reduces asthma exacerbations in 2- to 5-year-old children with intermittent asthma. Am J Respir Crit Care Med 2005; 171: 315-322.

189 Robertson CF, Price D, Henry R, et al. Short-course montelukast for intermittent asthma in children: a randomised controlled trial. Am J Respir Crit Care Med 2007; 175: 323-329.

190 Szefler SJ, Phillips BR, Martinez FD, et al. Characterization of within-subject responses to fluticasone and montelukast in childhood asthma. J Allergy Clin Immunol 2005; 115: 233-242.

191 de Benedictis FM, del Giudice MM, Forenza N, et al. Lack of tolerance to the protective effect of montelukast in exerciseinduced bronchoconstriction in children. Eur Respir J 2006; 28: 291-295.

192 Bisgaard H, Flores-Nunez A, Goh A, et al. Study of montelukast for the treatment of respiratory symptoms of post-respiratory syncytial virus bronchiolitis in children. Am J Respir Crit Care Med 2008; 178: 854-860.

193 Davis GM, Cooper DM, Mitchell I. The measurement of thoracoabdominal asynchrony in infants with severe laryngotracheobronchitis. Chest 1993; 103: 1842-1848.

194 Bjornson CL, Johnson DW. Croup-treatment update. Pediatr Emerg Care 2005; 21: 863-873.

195 Cherry JD. Croup. N Engl J Med 2008; 358: 384-391.

196 Bjornson CL, Johnson DW. Croup. Lancet 2008; 371: 329-339.

197 Moore M, Little P. Humidified air inhalation for treating croup. Cochrane Database Syst Rev 2006; 3: CD002870.

198 Scolnik D, Coates AL, Stephens D, et al. Controlled delivery of high versus low humidity versus mist therapy for croup in emergency departments: a randomized controlled trial. JAMA 2006; 295: 1274-1280.

199 Kairys SW, Olmstead EM, O'Connor GT. Steroid treatment of laryngotracheitis: a meta-analysis of the evidence from randomized trials. Pediatrics 1989; 83: 683-693.

200 Ausejo M, Saenz A, Pham B, et al. The effectiveness of glucocorticoids in treating croup: meta-analysis. BMJ 1999; 319: 595-600.

201 Russell K, Wiebe N, Saenz A, et al. Glucocorticoids for croup. Cochrane Database Syst Rev 2003; 4: CD001955.

202 Tibballs J, Shann FA, Landau LI. Placebo-controlled trial of prednisolone in children intubated for croup. Lancet 1992; 340: 745-748.

203 Geelhoed GC, Macdonald WB. Oral and inhaled steroids in croup: a randomized, placebo-controlled trial. Pediatr Pulmonol 1995; 20: 355-361.

204 Johnson DW, Jacobson S, Edney PC, et al. A comparison of nebulized budesonide, intramuscular dexamethasone, and placebo for moderately severe croup. N Engl J Med 1998; 339: 498-503.

205 Klassen TP, Craig WR, Moher D, et al. Nebulized budesonide and oral dexamethasone for treatment of croup: a randomized controlled trial. JAMA 1998; 279: 1629-1632.

206 Cetinkaya F, Tüfekçi BS, Kutluk G. A comparison of nebulized budesonide, and intramuscular, and oral dexamethasone for treatment of croup. Int J Pediatr Otorhinolaryngol 2004; 68: 453-456.
207 Geelhoed GC. Budesonide offers no advantage when added to oral dexamethasone in the treatment of croup. Pediatr Emerg Care 2005; 21: 359-362.

208 Rittichier KK, Ledwith CA. Outpatient treatment of moderate croup with dexamethasone: intramuscular versus oral dosing Pediatrics 2000; 106: 1344-1348.

209 Donaldson D, Poleski D, Knipple E, et al. Intramuscular versus oral dexamethasone for the treatment of moderate-to-severe croup: a randomized, double-blind trial. Acad Emerg Med 2003; 10: 16-21.

210 Amir L, Hubermann H, Halevi A, et al. Oral betamethasone versus intramuscular dexamethasone for the treatment of mild to moderate viral croup: a prospective, randomized trial. Pediatr Emerg Care 2006; 22: 541-544.

211 Sparrow A, Geelhoed G. Prednisolone versus dexamethasone in croup: a randomised equivalence trial. Arch Dis Child 2006; 91: 580-583.

212 Fifoot AA, Ting JY. Comparison between single-dose oral prednisolone and oral dexamethasone in the treatment of croup: a randomized, double-blinded clinical trial. Emerg Med Australas 2007; 19: 51-58

213 Geelhoed GC, Macdonald WB. Oral dexamethasone in the treatment of croup: $0.15 \mathrm{mg} \cdot \mathrm{kg}^{-1}$ versus $0.3 \mathrm{mg} \cdot \mathrm{kg}^{-1}$ versus $0.6 \mathrm{mg} \cdot \mathrm{kg}^{-1}$. Pediatr Pulmonol 1995; 20: 362-368.

214 Chub-Uppakarn S, Sangsupawanich P. A randomized comparison of dexamethasone $0.15 \mathrm{mg} \cdot \mathrm{kg}^{-1}$ versus $0.6 \mathrm{mg} \cdot \mathrm{kg}^{-1}$ for the treatment of moderate to severe croup. Int $J$ Pediatr Otorhinolaryngol 2007; 71: 473-477.

215 Mendes ES, Pereira A, Danta I, et al. Comparative bronchial vasoconstrictive efficacy of inhaled glucocorticosteroids. Eur Respir J 2003; 21: 989-993.

216 Taussig LM, Castro O, Beaudry $\mathrm{PH}$, et al. Treatment of laryngotracheobronchitis (croup): use of intermittent positivepressure breathing and racemic epinephrine. Am J Dis Child 1975; 129: 790-793.

217 Westley CR, Cotton EK, Brooks JG. Nebulized racemic epinephrine by IPPB for the treatment of croup: a double-blind study. Am J Dis Child 1978; 132: 484-487.

218 Fogel JM, Berg IJ, Gerber MA, et al. Racemic epinephrine in the treatment of croup: nebulization alone versus nebulization with intermittent positive pressure breathing. J Pediatr 1982; 101: 1028-1031.

219 Lenney W, Milner AD. Treatment of acute viral croup. Arch Dis Child 1978; 53: 704-706.

220 Corkey CW, Barker GA, Edmonds JF, et al. Radiographic tracheal diameter measurements in acute infectious croup: an objective scoring system. Crit Care Med 1981; 9: 587-590.

221 Fanconi S, Burger R, Maurer $\mathrm{H}$, et al. Transcutaneous carbon dioxide pressure for monitoring patients with severe croup J Pediatr 1990; 117: 701-705.

222 Sivan Y, Deakers TW, Newth CJ. Thoracoabdominal asynchrony in acute upper airway obstruction in small children. Am Rev Respir Dis 1990; 142: 540-544.

223 Steele DW, Santucci KA, Wright RO, et al. Pulsus paradoxus: an objective measure of severity in croup. Am J Respir Crit Care Med 1998; 157: 331-334.

224 Kristjánsson S, Berg-Kelly K, Winsö E. Inhalation of racemic adrenaline in the treatment of mild and moderately severe croup. Clinical symptom score and oxygen saturation measurements for evaluation of treatment effects. Acta Paediatr 1994; 83 1156-1160.

225 Waisman Y, Klein BL, Boenning DA, et al. Prospective randomized double-blind study comparing L-epinephrine and racemic epinephrine aerosols in the treatment of laryngotracheitis (croup). Pediatrics 1992; 89: 302-306.

226 Fitzgerald D, Mellis C, Johnson M, et al. Nebulized budesonide is as effective as nebulized adrenaline in moderately severe croup. Pediatrics 1996; 97: 722-725. 
227 Terregino CA, Nairn SJ, Chansky ME, et al. The effect of heliox on croup: a pilot study. Acad Emerg Med 1998; 5: 1130-1133.

228 Weber JE, Chudnofsky CR, Younger JG, et al. A randomized comparison of helium-oxygen mixture (Heliox) and racemic epinephrine for the treatment of moderate to severe croup. Pediatrics 2001; 107: E96.

229 Chiu CY, Wong KS, Huang YC, et al. Bronchiolitis obliterans in children: clinical presentation, therapy and long-term follow-up. J Paediatr Child Health 2008; 44: 129-133.

230 Chang AB, Masel JP, Masters B. Post-infectious bronchiolitis obliterans: clinical, radiological and pulmonary function sequelae. Pediatr Radiol 1998; 28: 23-29.

231 Moonnumakal SP, Fan LL. Bronchiolitis obliterans in children. Curr Opin Pediatr 2008; 20: 272-278.

232 Smith KJ, Fan LL. Insights into post-infectious bronchiolitis obliterans in children. Thorax 2006; 61: 462-463.

233 Castro-Rodriguez JA, Daszenies C, Garcia M, et al. Adenovirus pneumonia in infants and factors for developing bronchiolitis obliterans: a 5-year follow-up. Pediatr Pulmonol 2006; 41: 947-953.

234 Colom AJ, Teper AM, Vollmer WM, et al. Risk factors for the development of bronchiolitis obliterans in children with bronchiolitis. Thorax 2006; 61: 503-506.

235 Kim CK, Kim SW, Kim JS, et al. Bronchiolitis obliterans in the 1990s in Korea and the United States. Chest 2001; 120: 1101-1106.

236 Teper AM, Kofman CD, Maffey AF, et al. Lung function in infants with chronic pulmonary disease after severe adenoviral illness. J Pediatr 1999; 134: 730-733.

237 Cazzato S, Poletti V, Bernardi F, et al. Airway inflammation and lung function decline in childhood post-infectious bronchiolitis obliterans. Pediatr Pulmonol 2008; 43: 381-390.

238 Rossi UG, Owens CM. The radiology of chronic lung disease in children. Arch Dis Child 2005; 90: 601-607.

239 Clement A. Task force on chronic interstitial lung disease in immunocompetent children. Eur Respir J 2004; 24: 686-697.

240 Deutsch GH, Young LR, Deterding RR, et al. Diffuse lung disease in young children: application of a novel classification scheme. Am J Respir Crit Care Med 2007; 176: 1120-1128.

241 Deterding RR, Young LR, Dishop M. Diffuse lung disease in older children - report of the child network review. Am J Respir Crit Care Med 2007; 175: A148.

242 Osika E, Muller MH, Boccon-Gibod L, et al. Idiopathic pulmonary fibrosis in infants. Pediatr Pulmonol 1997; 23: 49-54.

243 Paul K, Klettke U, Moldenhauer J, et al. Increasing dose of methylprednisolone pulse therapy treats desquamative interstitial pneumonia in a child. Eur Respir J 1999; 14: 1429-1432.

244 Dinwiddie R, Sharief N, Crawford O. Idiopathic interstitial pneumonitis in children: a national survey in the United Kingdom and Ireland. Pediatr Pulmonol 2002; 34: 23-29.

$245 \mathrm{Kim} \mathrm{HB}$, Lee SY, Kim JH, et al. Familial interstitial lung disease in two young Korean sisters. J Korean Med Sci 2005; 20: 1066-1069.

246 Paiva MA, Amaral SM. Chronic interstitial lung disease in children. J Pediatr (Rio J) 2007; 83: 233-240.

247 Rigante D, Stabile A, Segni G. Chronic interstitial lung disease in a 10-year-old child. Clin Pediatr (Phila) 1998; 37: 697-699.

248 Uziel Y, Hen B, Cordoba M, et al. Lymphocytic interstitial pneumonitis preceding polyarticular juvenile rheumatoid arthritis. Clin Exp Rheumatol 1998; 16: 617-619.

249 Kobayashi I, Yamada M, Takahashi Y, et al. Interstitial lung disease associated with juvenile dermatomyositis: clinical features and efficacy of cyclosporin A. Rheumatology (Oxford) 2003; 42: 371-374.

250 Akikusa JD, Schneider R, Harvey EA, et al. Clinical features and outcome of pediatric Wegener's granulomatosis. Arthritis Rheum 2007; 57: 837-844.

251 Tamura N, Matsudaira R, Hirashima M, et al. Two cases of refractory Wegener's granulomatosis successfully treated with rituximab. Intern Med 2007; 46: 409-414.
252 Wilkinson NM, Erendzhinova E, Zeft A, et al. Infliximab as rescue therapy in three cases of paediatric Wegener's granulomatosis. Rheumatology (Oxford) 2006; 45: 1047-1048.

253 Hermon MM, Golej J, Emminger W, et al. Acute hemorrhagic respiratory failure caused by Wegener's granulomatosis successfully treated by bronchoalveolar lavage with diluted surfactant. Wien Klin Wochenschr 2003; 115: 793-796.

254 Kamali S, Cefle A, Sayarlioglu M, et al. Experience with monthly, high-dose, intravenous immunoglobulin therapy in patients with different connective tissue diseases. Rheumatol Int 2005; 25: 211-214.

255 Morimoto A, Ikushima S, Kinugawa N, et al. Improved outcome in the treatment of pediatric multifocal Langerhans cell histiocytosis: results from the Japan Langerhans Cell Histiocytosis Study Group-96 protocol study. Cancer 2006; 107: 613-619.

256 Hartl D, Griese M. Interstitial lung disease in children - genetic background and associated phenotypes. Respir Res 2005; 6: 32.

257 Price A, Manson D, Cutz E, et al. Pulmonary alveolar proteinosis associated with anti-GM-CSF antibodies in a child: successful treatment with inhaled GM-CSF. Pediatr Pulmonol 2006; 41: 367-370.

258 Mahut B, de Blic J, Le Bourgeois M, et al. Partial and massive lung lavages in an infant with severe pulmonary alveolar proteinosis. Pediatr Pulmonol 1992; 13: 50-53.

259 Mahut B, Delacourt C, Scheinmann P, et al. Pulmonary alveolar proteinosis: experience with eight pediatric cases and a review. Pediatrics 1996; 97: 117-122.

260 Spock A. Long-term survival of paediatric patients with pulmonary alveolar proteinosis treated with lung lavage. Eur Respir J 2005; 25: 1127.

261 Froudarakis ME, Koutsopoulos A, Mihailidou HP. Total lung lavage by awake flexible fiberoptic bronchoscope in a 13-yearold girl with pulmonary alveolar proteinosis. Respir Med 2007; 101: 366-369.

262 Ceruti M, Rodi G, Stella GM, et al. Successful whole lung lavage in pulmonary alveolar proteinosis secondary to lysinuric protein intolerance: a case report. Orphanet J Rare Dis 2007; 2: 14.

263 Desmarquest $\mathrm{P}$, Tamalet A, Fauroux B, et al. Chronic interstitial lung disease in children: response to high-dose intravenous methylprednisolone pulses. Pediatr Pulmonol 1998; 26: 332-338.

264 Kiper N, Anadol D, Ozcelik U, et al. Inhaled corticosteroids for maintenance treatment in childhood pulmonary sarcoidosis. Acta Paediatr 2001; 90: 953-956.

265 Hilton JM, Cooper DM, Henry RL, et al. Hydroxychloroquine therapy of diffuse pulmonary sarcoidosis in two Australian male children. Respirology 1997; 2: 71-74.

266 Moudgil A, Przygodzki RM, Kher KK. Successful steroidsparing treatment of renal limited sarcoidosis with mycophenolate mofetil. Pediatr Nephrol 2006; 21: 281-285.

267 Brik R, Gepstein V, Shahar E, et al. Tumor necrosis factor blockade in the management of children with orphan diseases. Clin Rheumatol 2007; 26: 1783-1785.

268 Cruz BA, Reis DD, Araujo CA, et al. Refractory retinal vasculitis due to sarcoidosis successfully treated with infliximab. Rheumatol Int 2007; 27: 1181-1183.

269 Minakuchi M, Niimi A, Matsumoto $\mathrm{H}$, et al. Chronic eosinophilic pneumonia: treatment with inhaled corticosteroids. Respiration 2003; 70: 362-366.

270 Bush A, Sheppard MN, Warner JO. Chloroquine in idiopathic pulmonary haemosiderosis. Arch Dis Child 1992; 67: 625-627.

271 Rossi GA, Balzano E, Battistini E, et al. Long-term prednisone and azathioprine treatment of a patient with idiopathic pulmonary hemosiderosis. Pediatr Pulmonol 1992; 13: 176-180.

272 Zaki M, al Saleh Q, al Mutari G. Effectiveness of chloroquine therapy in idiopathic pulmonary hemosiderosis. Pediatr Pulmonol 1995; 20: 125-126. 
273 Kiper N, Göçmen A, Ozçelik U, et al. Long-term clinical course of patients with idiopathic pulmonary hemosiderosis (1979-1994): prolonged survival with low-dose corticosteroid therapy. Pediatr Pulmonol 1999; 27: 180-184.

274 Colombo JL, Stolz SM. Treatment of life-threatening primary pulmonary hemosiderosis with cyclophosphamide. Chest 1992; 102: 959-960.

275 Huang SH, Lee PY, Niu CK. Treatment of pediatric idiopathic pulmonary hemosiderosis with low-dose cyclophosphamide. Ann Pharmacother 2003; 37: 1618-1621.

276 Sharief N, Crawford OF, Dinwiddie R. Fibrosing alveolitis and desquamative interstitial pneumonitis. Pediatr Pulmonol 1994; 17: 359-365.

277 Balasubramanyan N, Murphy A, O'Sullivan J, et al. Familial interstitial lung disease in children: response to chloroquine treatment in one sibling with desquamative interstitial pneumonitis. Pediatr Pulmonol 1997; 23: 55-61.

278 Stauffer Ettlin M, Pache JC, Renevey F, et al. Bird breeder's disease: a rare diagnosis in young children. Eur J Pediatr 2006; 165: 55-61.
279 du Marchie Sarvaas GJ, Merkus PJ, de Jongste JC. A family with extrinsic allergic alveolitis caused by wild city pigeons: a case report. Pediatrics 2000; 105: E62.

280 Aebischer CC, Frey U, Schöni MH. Hypersensitivity pneumonitis in a five-year-old boy: an unusual antigen source. Pediatr Pulmonol 2002; 33: 77-78.

281 Chen C, Kleinau I, Niggemann B, et al. Treatment of allergic alveolitis with methylprednisolone pulse therapy. Pediatr Allergy Immunol 2003; 14: 66-70.

282 Deutsch GH, Young LR, Deterding RR, et al. ChILD Research Cooperative. Diffuse lung disease in young children: application of a novel classification scheme. Am J Respir Crit Care Med 2007; 176: $1120-1128$.

283 Deterding RR, Pye C, Fan LL, et al. Persistent tachypnea of infancy is associated with neuroendocrine cell hyperplasia. Pediatr Pulmonol 2005; 40: 157-165.

284 Canakis AM, Cutz E, Manson D, et al. Pulmonary interstitial glycogenosis: a new variant of neonatal interstitial lung disease. Am J Respir Crit Care Med 2002; 165: 1557-1565. 